\title{
The evidence supporting the use of honey as a wound dressing
}

\author{
P. C. Molan B.Sc. Ph.D. \\ Director of the Honey Research Unit, Department of Biological Sciences, University of \\ Waikato, Hamilton, New Zealand
}

Corresponding author: Professor P. C. Molan
Department of Biological Sciences
University of Waikato
Private Bag 3105
Hamilton
New Zealand
$\begin{array}{ll}\text { Telephone: } & +6478384325 \\ \text { Fax: } & +6478384324 \\ \text { E-mail: } & \text { pmolan@waikato.ac.nz }\end{array}$




\section{ABSTRACT}

Some clinicians are under the impression that there is little or no evidence to support the use of honey as a wound dressing. This impression is reinforced by it being concluded in systematic reviews that the evidence is not of a high standard. But likewise the evidence for modern wound dressing products is of not of a high standard. For evidence-based medicine to be practised in wound care, when deciding which product to use to dress a wound it is necessary to compare the evidence that does exist, rather than be influenced by advertising and other forms of sales promotion. To allow sound decisions to be made, this review has covered the various reports that have been published on the clinical usage of honey. Positive findings on honey in wound care have been reported from 17 randomised controlled trials involving a total of 1965 participants, and 5 clinical trials of other forms involving 97 participants treated with honey. The effectiveness of honey in assisting wound healing has also been demonstrated in 16 trials on a total of 533 wounds on experimental animals. There is also a large amount of evidence in the form of case studies that have been reported. Ten publications have reported on multiple cases, totalling 276 cases. There are also 35 reports of single cases. These various reports provide a large body of evidence to support honey having the beneficial actions of clearing and preventing wound infection, rapidly debriding wounds, suppressing inflammation and thus decreasing oedema, wound exudate and hypertophic scarring, and stimulating the growth of granulation tissue and epithelialisation. It has been shown to give good results on a very wide range of types of wound. Clinicians should look for the clinical evidence that exists to support the use of other wound care products to compare with the evidence that exists for honey.

Key words: evidence, honey, infected wounds, surgical wounds, burns, ulcers, abscesses, skin grafts, moist dressings, non-stick, debriding, deodorising, antibacterial, anti-inflammatory, prevention of scarring 
There is a rapidly increasing interest in the use of honey as a wound dressing, but it is common to hear clinicians express the opinion that there is no evidence to support the use of honey as a wound dressing. However, the impression upon which this opinion is based is most likely to be a reflection of the scarcity of advertising and other commercial promotion of honey for wound care relative to that of other wound care products. Even where reviews of clinical evidence for the use of honey have been published, a negative impression is often obtained from consulting these, as the conclusions stated are that the evidence is of low quality and/or that there is a need for more evidence. ${ }^{1-6}$ But the myriad of advertisements for modern wound dressings possibly blinds people to the fact that only small, poor-quality trials exist to support the use of these products. ${ }^{7}$ For example, if the PubMed database is searched for evidence to support the use of nanocrystalline silver dressings, which are very heavily promoted, it can be seen that there is in fact very little clinical evidence that has been published. A recent systematic review of publications on the use of advanced dressings in the treatment of pressure ulcers has found that their generalised use in the treatment of pressure ulcers is not supported by good research evidence. ${ }^{8}$ In evidence-based medicine decisions should be made on the basis of the available evidence: where randomised controlled trials of the highest quality have not been conducted, then it is necessary to consider evidence of a lower quality. It is for these reasons that this review has been written, to allow clinicians to see the large amount of evidence that exists for the effectiveness of honey as a wound dressing. By comparing this with the evidence for other wound-care products clinicians can then judge for themselves the relative merits of honey as a treatment option for wounds.

The literature cited was found by searching the PubMed, BIOSIS and ISI Web of Science databases for the term "honey". Also, literature not included in the databases was found from citations in papers that were. Excluded were papers where honey was used in a mixture with other therapeutic substances, papers giving brief reports on the use of honey on cases where there was insufficient information on the cases given for the reader to judge if the positive outcomes were the result of honey being more effective than the prior treatment, and papers that were expressions of opinion rather than reports of treatment of wounds with honey. Conference presentations were also excluded.

\section{CLINICAL EVIDENCE}


Many randomised controlled trials have been carried out comparing honey with various other wound treatments. These trials and the results obtained from them are summarised in Table 1. Other clinical trials have been conducted where the form of the trial has been other than a randomised controlled trial. In some of these the results for the group of patients treated with honey were compared retrospectively with those from the control treatment. In others the patients were crossed over to treatment with honey after a period of the treatment normally used for that type of wound. The details of these trials and the results obtained from them are summarised in Table 2 . Some of the case studies reported for single cases have also involved a comparative study. In these the patient has had multiple wounds, so honey could be used on one side and the usual treatment on the other. The details of these are summarised in Table 3.

There have also been many non-comparative studies reported on the use of honey as a wound dressing. Since many of these cases were not responding to standard treatment for quite some time before dressing with honey was commenced, these provide evidence that is somewhat like that from a cross-over trial, although these studies involved no reverse change in treatment like would be done in a cross-over trial. Some of these studies have been with multiple cases. The details of these are summarised in Table 4. The details of studies of single cases are summarised in Table 5.

\section{EVIDENCE FROM ANIMAL EXPERIMENTS}

Many studies have been carried on the effectiveness of honey in promoting the healing of standardised wounds created on experimental animals. These experiments have not only allowed there to be much more closely comparable controls in trials, but also have allowed histological examination of the healing wounds to provide additional data besides the usual measurements of decrease in wound size and time to heal. These experiments and the results obtained from them are summarised in Table 6.

\section{DISCUSSION}

The evidence presented in this review amply demonstrates that honey, the oldest wound dressing material known to medicine, can give positive results where the most modern 
products are failing. Because people generally are unaware of the historical usage of honey as a wound dressing, or know only of its ancient usage, its clinical usage is presumed to be a new development or something that has been "rediscovered". However, a look at the reference list at the end of this paper will reveal reports of clinical usage published in the $1950 \mathrm{~s},{ }^{10,11} 1960 \mathrm{~s},{ }^{12} 1970 \mathrm{~s},{ }^{13-16}$ and $1980 \mathrm{~s}^{17-23}$ as well as the rapidly increasing number since it apparent "rediscovery". Clinicians need to decide if modern wound-care products are likely to give better results than this long-established wound dressing material.

The evidence presented here that supports the use of honey in wound care includes evidence from many clinical trials. However, none of the findings from these trials would be considered to be evidence of the very highest level, because even though they may have been randomised controlled trials they have not been doubleblind. It is near impossible to conduct a double-blind trial of honey as a wound dressing, because of the difficulty of keeping obscured from the patients that a material as recognisable as honey is being used. Even if honey is applied in the form of a manufactured dressing, its aroma is immediately recognised. For this reason there is always the possibility that positive results achieved with honey will be partly due to a placebo effect.

However, there are trials and case studies in which the honey and the comparative treatment were used simultaneously on the same patient. These demonstrate that positive results achieved with honey are not just a placebo effect. One of these was a prospective randomised controlled trial of honey on split-thickness skin graft donor sites $^{24}$ (the last item in Table 1). On patients in this trial who had single donor sites (three groups of 14 patients), half of the donor site was treated with honey and half with the comparative treatment. On patients with two donor sites (three groups of 15 patients) one of the donor sites was treated with honey and one with the comparative treatment. (Honey was compared with three controls, saline-soaked gauze, paraffin gauze and a hydrocolloid.) In that trial, the significantly faster healing rates and lower pain scores achieved with honey compared with saline-soaked gauze and paraffin gauze clearly would have been due to physical effects of the honey and not to psychosomatic effects. Further evidence of a similar nature is seen in the results achieved in the case studies summarised in Table 3, although unlike with the trial with the skin graft donor sites where the wounds being compared were of a standard nature, 
there is a possibility the wounds given different treatment for comparison may not have been identical when treatment was started.

The most convincing evidence for the results with honey not being due to a placebo effect comes from the many studies that demonstrated the effectiveness of honey on standard wounds inflicted on experimental animals. Although the participants in these trials may well have been able to detect by smell that honey was being used they would not have had any psychosomatic effects on healing resulting from beliefs that natural products would be more effective, or from hearing via the news media of the effectiveness of honey in wound treatment.

Another factor that many say may be the reason why honey gives good results in individual cases studied is that wound healing improves whenever wounds are receiving more attention, or that the prior treatment was less than ideal. However, in many of the cases summarised in Table 5 the wounds were receiving specialist care before honey was used. They changed to healing from non-healing only when treatment with honey was commenced. In many of these cases the wounds were not responding to best practice with modern dressings, although a recent systematic review of the evidence for the efficacy of modern wound dressings in the treatment of pressure ulcers has concluded that there is no evidence that these are any better than saline-soaked gauze. 8

Further evidence to support the use of honey as a wound dressing comes from laboratory studies that have clearly demonstrated that honey has bioactivities that would be beneficial in wound care. In work with cultures of leukocytes, honey has been shown to stimulate cytokine production by monocytes. ${ }^{25,26}$ The release of cytokines is what initiates the tissue repair process as well as the immune response to infection. Also, simulation by honey of other aspects of the immune response, the proliferation of $\mathrm{B}$ - and T-lymphocytes and the activity of phagocytes, has been shown. ${ }^{27}$ Additional to this work with cells in culture, it has been demonstrated that honey stimulates the production of antibodies in mice in response to antigens from Escherichia coli. ${ }^{28}$ These findings suggest that part of the effectiveness of honey in clearing and preventing infection in wounds that is so widely seen in the clinical evidence may be due to enhancement of the body's own immunity as well as being due to the antibacterial activity of honey.

The number of publications on laboratory studies showing that honey has antibacterial activity with a very broad spectrum is very large.$^{29}$ But what is often not taken into account is that honeys can vary as much as 100 -fold in the potency of their 
antibacterial activity. ${ }^{30}$ More recent publications have reported on the sensitivity of various species of bacteria to honey with antibacterial potency near the median level found in surveys of large numbers of samples. (This level is a little below that of the various honey wound-care products now on sale manufactured from Leptospermum honey, but there are other wound-care products manufactured from honeys not selected to have high levels of antibacterial activity. ${ }^{31}$ ) Laboratory studies with Leptospermum (manuka) honey with antibacterial potency near the median level have shown the MIC (minimum inhibitory concentration, i.e. the concentration down to which honey could be diluted by wound exudate and still prevent bacterial growth) to be $2-3 \%$ for Staphylococcus aureus, ${ }^{32} 3.3-4 \%$ for coagulase-negative staphylococci, ${ }^{33} 5.5-9 \%$ for pseudomonads, ${ }^{34,35} 2.7-3 \%$ for MRSA, ${ }^{36}$ and $3.8-5 \%$ for VRE. ${ }^{36}$. (The effectiveness of honey in clinical usage in clearing infection with $\mathrm{MRSA}^{37-41}$ and $\mathrm{VRE}^{40}$ has been reported.) The slow clearance of infection, or failure to clear infection, in some of the cases reported may well reflect the use of honey with a low antibacterial potency. For example, this may have been the case in the randomised controlled trial where honey was found to be less effective than early tangential excision followed by autologous skin grafting in controlling infection in the treatment of burns. ${ }^{42}$ The same author, publishing results comparing the MIC values for various types of honey available locally, reported that the MIC for the most potent honey against Staphylococcus aureus was $20-25 \%{ }^{43}$ which means that the honey had only about one tenth of the antibacterial potency of the Leptospermum honey used in wound-care products now on sale.

Another reason for variability in results may have been that the honey in some cases was not being kept in place on the wound. The difficulty of achieving this has been commented on. ${ }^{44,45}$ If the honey is flushed out of the dressing by wound exudate then its various bioactivities cannot be having any effect on the wound. A case which may be an example of this is where infection in a leg ulcer was reported to recur when compression was commenced. ${ }^{46}$ Here it was noted that there was a problem with dressings adhering, which is a clear indication that honey has been flushed out of the dressing by wound exudate. ${ }^{47} \mathrm{~A}$ similar occurrence was reported where honeyimpregnated tulle dressings were being used. ${ }^{48}$ These have very little absorbency so honey is easily flushed from them. It was noted in this case that the dressings became saturated with exudate within one hour. In another case where poor progress was occurring with honey it was found that much better progress with healing occurred when more frequent changes of the dressings were made. ${ }^{49}$ 
It has been noted that if sufficient honey is kept in place, by applying it by way of impregnated dressings and changing these frequently enough, then its antiinflammatory activity will reduce the amount of exudate and thus remove the need for frequent dressing changes. ${ }^{47}$ There is a very large amount of evidence for honey having significant anti-inflammatory activity. As well as the evidence that has come from the many clinical observations summarised in this review there is evidence from histological observation of biopsy samples taken in a clinical trial of honey on burns, ${ }^{50}$ and from biochemical assays of indicators of inflammation in other clinical trials on burns. ${ }^{51,52}$ One of these biochemical studies was in the form of a randomised controlled trial with 60 patients, comparing honey with silver sulfadiazine, and it was demonstrated that honey decreased oxidative stress by mopping up the free radicals arising from burns. ${ }^{52}$ There is also histological evidence for the anti-inflammatory activity of honey from some of the studies on experimental animals summarised in Table 6. In some of the experimentally induced burns there was no infection evident, yet honey still brought about a decrease in inflammation. This indicates that the anti-inflammatory activity of honey is a direct action and not a secondary consequence of removal of infection through its antibacterial activity. This is confirmed also by honey giving a positive result in the standard guineapig wrist stiffness test for anti-inflammatory activity. ${ }^{53}$ That honey has a direct antiinflammatory activity is also indicated by it being found that honey was as effective as prednisolone in a trial on induced colitis in rats,${ }^{54}$ and by it being found to give a highly significant $(p<0.001)$ reduction in peritoneal adhesions following surgery on the caecum

and ileum in another trial on rats. ${ }^{55} \mathrm{~A}$ laboratory study also demonstrated a direct antiinflammatory activity in honey, as honey was shown to significantly $(p<0.001)$ decrease the amount of reactive oxygen intermediates released from monocytes in culture that had been stimulated with Escherichia coli lipopolysachharide.

\section{CONCLUSIONS}

There is a large body of evidence to support the use of honey as a wound dressing for a wide range of types of wound. Its antibacterial activity rapidly clears infection and protects wounds from becoming infected, thus it provides a moist healing environment without the risk of bacterial growth occurring. It. also rapidly debrides wounds and removes malodour. Its anti-inflammatory activity reduces oedema and exudate, and prevents or minimises hypertrophic scarring. It also stimulates the growth of granulation 
tissue and epithelial tissue so that healing is hastened. Furthermore, it creates a nonadherent interface between the wound and the dressing so that dressings may be easily removed without pain or damage to newly re-grown tissue

The barrier to using honey that has existed for many clinicians who have been constrained to using only licensed products has been removed now that honey is available in the form of various sterile products licensed for use in wound care. To practise evidence-based medicine, clinicians involved in wound care thus should check what evidence exists for other wound dressing products they may be considering using, and weigh this up against the evidence that exists to support the use of honey.

\section{REFERENCES}

1. Office of Complementary Medicines. Honey Scientific Report. (On line) http://wwwtgagovau/docs/pdf/cmec/honeysrpdf 1998.

2. Fox $\mathrm{C}$. Honey as a dressing for chronic wounds in adults. $\mathrm{Br} \mathrm{J}$ Community Nurs 2002;7(10):530-4.

3. Gethin G. Is there enough clinical evidence to use honey to manage wounds? J Wound Care 2004;13(7):275-278.

4. Moore OA, Smith LA, Campbell F, et al. Systematic review of the use of honey as a wound dressing. BMC Complement Altern Med 2001;1(1):2.

5. Mwipatayi BP, Angel D, Norrish J, et al. The use of honey in chronic leg ulcers: a literature review. Primary Intention 2004;12(3):107-112.

6. Templeton S. A review of the use of honey on wounds. ACCNS J Community Nurs 2002;7(1):13-14.

7. Vermeulen H, Ubbink DT, Goossens A, et al. Systematic review of dressings and topical agents for surgical wounds healing by secondary intention. Br J Surg 2005;92(6):665-72.

8. Bouza C, Saz Z, Muñoz A, et al. Efficacy of advanced dressings in the treatment of pressure ulcers: a systematic review. J Wound Care 2005;14(5):193-9.

9. Zumla A, Lulat A. Honey - a remedy rediscovered. J R Soc Med 1989;82(7):384-385.

10. Seymour FI, West KS. Honey - its role in medicine. Med Times 1951;79:104-107.

11. Bulman MW. Honey as a surgical dressing. Middlesex Hosp J 1955;55:188-189.

12. Hutton DJ. Treatment of pressure sores. Nurs Times 1966;62(46):1533-1534. 
13. Cavanagh D, Beazley J, Ostapowicz F. Radical operation for carcinoma of the vulva. A new approach to wound healing. J Obstet Gynaecol Br Commonw 1970;77(11):1037-1040.

14. Blomfield R. Honey for decubitus ulcers. J Am Med Assoc 1973;224(6):905.

15. Bloomfield E. Old remedies. J R Coll Gen Pract 1976;26:576.

16. Burlando F. Sull'azione terapeutica del miele nelle ustioni. Minerva Dermatol 1978;113:699-706.

17. Efem SEE. Clinical observations on the wound healing properties of honey. $\mathrm{Br} \mathrm{J}$ Surg 1988;75:679-681.

18. Farouk $A$, Hassan $T$, Kashif $H$, et al. Studies on Sudanese bee honey: laboratory and clinical evaluation. Int J Crude Drug Res 1988;26(3):161-168.

19. Armon PJ. The use of honey in the treatment of infected wounds. Trop Doct 1980;10:91.

20. Bergman A, Yanai J, Weiss J, et al. Acceleration of wound healing by topical application of honey. An animal model. Am J Surg 1983;145:374-376.

21. Braniki FJ. Surgery in Western Kenya. Ann R Coll Surg Engl 1981;63:348-352.

22. Green AE. Wound healing properties of honey. Br J Surg 1988;75(12):1278.

23. Wadi M, Al-Amin H, Farouq A, et al. Sudanese bee honey in the treatment of suppurating wounds. Arab Medico 1987;3:16-18.

24. Misirlioglu A, Eroglu S, Karacaoglan N, et al. Use of honey as an adjunct in the healing of split-thickness skin graft donor site. Dermatol Surg 2003;29(2):168-72.

25. Tonks A, Cooper RA, Price AJ, et al. Stimulation of TNF-a release in monocytes by honey. Cytokine 2001;14(4):240-242.

26. Tonks AJ, Cooper RA, Jones KP, et al. Honey stimulates inflammatory cytokine production from monocytes. Cytokine 2003;21(5):242-7.

27. Abuharfeil N, Al-Oran R, Abo- Shehada M. The effect of bee honey on proliferative activity of human B- and T-lymphocytes and the activity of phagocytes. Food Agric Immunol 1999;11:169-177.

28. Al-Waili NS, Haq A. Effect of honey on antibody production against thymusdependent and thymus-independent antigens in primary and secondary immune responses. J Med Food 2004;7(4):491-4.

29. Molan PC. The antibacterial activity of honey. 1. The nature of the antibacterial activity. Bee World 1992;73(1):5-28. 
30. d'Agostino Barbaro A, La Rosa C, Zanelli C. Atttività antibatterica di mieli Siciliani. Quad Nutr 1961;21(1/2):30-44.

31. Molan PC, Betts JA. Clinical usage of honey as a wound dressing: an update. J Wound Care 2004;13(9):353-6.

32. Cooper RA, Molan PC, Harding KG. Antibacterial activity of honey against strains of Staphylococcus aureus from infected wounds. J R Soc Med 1999;92(6):283-285.

33. French VM, Cooper RA, Molan PC. The antibacterial activity of honey against coagulase-negative staphylococci. J Antimicrob Chemother 2005;56(1):228-31.

34. Cooper RA, Halas E, Molan PC. The efficacy of honey in inhibiting strains of Pseudomonas aeruginosa from infected burns. J Burn Care Rehabil 2002;23(6):366-370.

35. Cooper RA, Molan PC. The use of honey as an antiseptic in managing Pseudomonas infection. J Wound Care 1999;8(4):161-164.

36. Cooper RA, Molan PC, Harding KG. The sensitivity to honey of Gram-positive cocci of clinical significance isolated from wounds. J Appl Microbiol 2002;93:857-863.

37. Dunford C, Cooper R, Molan PC, et al. The use of honey in wound management. Nurs Standard 2000;15(11):63-68.

38. Natarajan S, Williamson D, Grey J, et al. Healing of an MRSA-colonized, hydroxyurea-induced leg ulcer with honey. J Dermatolog Treat 2001;12:33-36.

39. Dunford CE. Treatment of a wound infection in a patient with mantle cell lymphoma. Br J Nurs 2001;10(16):1058-1065.

40. Eddy JJ, Gideonsen MD. Topical honey for diabetic foot ulcers. J Fam Pract 2005;54(6):533-5.

41. Simon A, Sofka K, Wiszniewsky G, et al. Wound care with antibacterial honey (Medihoney) in pediatric hematology-oncology. Support Care Cancer 2005; (In press).

42. Subrahmanyam M. Early tangential excision and skin grafting of moderate burns is superior to honey dressing: a prospective randomised trail. Burns 1999;25(8):729731.

43. Subrahmanyam M, Hemmady AR, Pawar SG. Mutlidrug-resistant Staphylococcus aureus isolated from infected burns sensitive to honey. Ann Burns Fire Disasters 2003;16(4):192-4.

44. Alcaraz A, Kelly J. Treatment of an infected venous leg ulcer with honey dressings. Br J Nurs 2002;11(13):859-60, 862, 864-6. 
45. Lawrence JC. Editorial: Honey and wound bacteria. J Wound Care 1999;8(4):155.

46. Kingsley A. A proactive approach to wound infection. Nurs Standard 2001;15(30):508.

47. Molan PC, Betts J. Using honey dressings: the practical considerations. Nurs Times 2000;96(49):36-37.

48. Kingsley A. Practical use of modern honey dressings in chronic wounds. In: White R, Cooper R, Molan P, editors. Honey: A modern wound management product. Aberdeen, UK: Wounds UK Publishing, 2005:54-78.

49. van der Weyden EA. Treatment of a venous leg ulcer with a honey alginate dressing. Br J Community Nurs 2005;10(6 Suppl):S21, S24, S26-7.

50. Subrahmanyam M. A prospective randomised clinical and histological study of superficial burn wound healing with honey and silver sulfadiazine. Burns 1998;24(2):157-161.

51. Subrahmanyam M, Sahapure AG, Nagane NS, et al. Effects of topical application of honey on burn wound healing. Ann Burns Fire Disasters 2001;XIV(3):143-145.

52. Subrahmanyam M, Shahapure AG, Nagane NS, et al. Free radical control - the main mechanism of the action of honey in burns. Ann Burns Fire Disasters 2003;16(3):135-8.

53. Church J. Honey as a source of the anti-stiffness factor. Fed Proc Am Physiol Soc 1954;13(1):26.

54. Bilsel Y, Bugra D, Yamaner S, et al. Could honey have a place in colitis therapy? Effects of honey, prednisolone, and disulfiram on inflammation, nitric oxide, and free radical formation. Dig Surg 2002;19:306-312.

55. Aysan E, Ayar E, Aren A, et al. The role of intra-peritoneal honey administration in preventing post-operative peritoneal adhesions. Eur J Obstet Gynecol Reprod Biol 2002;104(2):152-155.

56. Subrahmanyam M. Topical application of honey in treatment of burns. Br J Surg 1991;78(4):497-498.

57. Subrahmanyam M. Honey impregnated gauze versus polyurethane film (OpSite ${ }^{\circledR}$ ) in the treatment of burns - a prospective randomised study. Br J Plast Surg 1993;46(4):322-323.

58. Subrahmanyam M. Honey-impregnated gauze versus amniotic membrane in the treatment of burns. Burns 1994;20(4):331-333. 
59. Subrahmanyam N. Addition of antioxidants and polyethylene glycol 4000 enhances the healing property of honey in burns. Ann Burns Fire Disasters 1996;9(2):93-95.

60. Subrahmanyam M. Honey dressing versus boiled potato peel in the treatment of burns: a prospective randomized study. Burns 1996;22(6):491-493.

61. Bangroo AK, Katri R, Chauhan S. Honey dressing in pediatric burns. J Indian Assoc Pediatr Surg 2005;10(3):172-5.

62. Nagra ZM, Fayyaz GQ, Asim M. Honey dressings; Experience at Department of Plastic Surgery and burns Allied Hospital Faisalabad. Prof Med J 2002;9(3):24651.

63. AI-Waili NS, Saloom KY. Effects of topical honey on post-operative wound infections due to gram positive and gram negative bacteria following caesarean sections and hysterectomies. Eur J Med Res 1999;4:126-130.

64. Okeniyi JAO, Olubanjo OO, Ogunlesi TA, et al. Comparison of healing of incised abscess wounds with honey and EUSOL dressing. J Altern Complement Med 2005;11(3):511-513.

65. Oluwatosin OM, Olabanji JK, Oluwatosin OA, et al. A comparison of topical honey and phenytoin in the treatment of chronic leg ulcers. Afr J Med Sci 2000;29(1):3134.

66. Weheida SM, Nagubib HH, El-Banna HM, et al. Comparing the effects of two dressing techniques on healing of low grade pressure ulcers. J Med Res Inst Alexandria Univ 1991;12(2):259-278.

67. Mutjaba Quadri KH. Manuka honey for central vein catheter exit site care. Semin Dial 1999;12(5):397-398.

68. Johnson DW, van Eps C, Mudge DW, et al. Randomized, controlled trial of topical exit-site application of honey (Medihoney) versus mupirocin for the prevention of catheter-associated infections in hemodialysis patients. J Am Soc Nephrol 2005;16(5):1456-62.

69. Phuapradit W, Saropala N. Topical application of honey in treatment of abdominal wound disruption. Aust N Z J Obstet Gynaecol 1992;32(4):381-384.

70. Efem SEE. Recent advances in the management of Fournier's gangrene: Preliminary observations. Surgery 1993;113(2):200-204.

71. Vardi A, Barzilay Z, Linder N, et al. Local application of honey for treatment of neonatal postoperative wound infection. Acta Paediatr 1998;87(4):429-432. 
72. Dunford CE, Hanano R. Acceptability to patients of a honey dressing for non-healing venous leg ulcers. J Wound Care 2004;13(5):193-197.

73. Adesunkanmi K, Oyelami OA. The pattern and outcome of burn injuries at Wesley Guild Hospital, llesha, Nigeria: a review of 156 cases. J Trop Med Hyg 1994;97(2):108-112.

74. Harris S. Honey for the treatment of superficial wounds: a case report and review. Primary Intention 1994;2(4):18-23.

75. Dany-Mazeau MPG. Honig auf die Wunde. Krankenpflege 1992;46(1):6-10.

76. Taks JM. Eusol managment of burns. Trop Doct 2000;30:54.

77. Ahmed AK, Hoekstra MJ, Hage JJ, et al. Honey-medicated dressing: transformation of an ancient remedy into modern therapy. Ann Plast Surg 2003;50(2):143-7; discussion 147-8.

78. Ndayisaba G, Bazira L, Habonimana E, et al. Clinical and bacteriological results in wounds treated with honey. J Orthop Surg 1993;7(2):202-204.

79. Stephen-Haynes J. Evaluation of a honey-impregnated tulle dressing in primary care. Br J Community Nurs 2004;Suppl:S21-7.

80. Schumacher $\mathrm{HH}$. Use of medical honey in patients with chronic venous leg ulcers after split-skin grafting. J Wound Care 2004;13(10):451-2 .

81. Hejase MJ, E. SJ, Bihrle R, et al. Genital Fournier's gangrene: experience with 38 patients. Urology 1996;47(5):734-739.

82. Anoukoum T, Attipou KK, Ayite A, et al. Le traitment des gangrenes perineales et de la sphere genitale par du miel. Tunis Med 1998;76(5):132-135.

83. Dunford $C$. The use of honey-derived dressings to promote effective wound management. Prof Nurse 2005;20(8):35-8.

84. Kingsley A. The use of honey in the treatment of infected wounds: case studies. $\mathrm{Br} \mathrm{J}$ Nurs 2001;10(22, Tissue Viability Supplement):S13-S20.

85. Van der Weyden EA. The use of honey for the treatment of two patients with pressure ulcers. Br J Community Nurs 2003;8(12 Suppl):S14-S20.

86. Stephen-Haynes J. Implications of honey dressings within primary care. In: White $\mathrm{R}$, Cooper R, Molan P, editors. Honey: A modern wound management product. Aberdeen, UK: Wounds UK Publishing, 2005:33-53.

87. Robson V. Use of Leptospermum honey in chronic wound management. J Community Nurs 2004;18(9):24-28.

88. Abenavoli FM, Corelli R. Honey therapy. Ann Plast Surg 2004;52(6):627. 
89. Cooper RA, Molan PC, Krishnamoorthy L, et al. Manuka honey used to heal a recalcitrant surgical wound. Eur J Microbiol Infect Dis 2001;20:758-9.

90. Robson V, Martin L, Cooper R. The use of Leptospermum honey on chronic wounds in breast care. In: White R, Cooper R, Molan P, editors. Honey: A modern wound management product. Aberdeen, UK: Wounds UK Publishing, 2005:103-115.

91. Dunford C, Cooper R, Molan PC. Using honey as a dressing for infected skin lesions. Nurs Times 2000;96(14 NT-plus):7-9.

92. Postmes TJ, Bosch MMC, Dutrieux R, et al. Speeding up the healing of burns with honey. An experimental study with histological assessment of wound biopsies. In: Mizrahi A, Lensky Y, editors. Bee Products: Properties, Applications and Apitherapy. New York: Plenum Press, 1997:27-37.

93. Kabala-Dzik A, Stojko R, Szaflarska-Stojko E, et al. Influence of honey-balm on the rate of scare formation during experimental burn wound healing in pigs. Bulletin of the Veterinary Institute in Pulawy 2004;48(3):311-316.

94. Miri MR, Hemmati H, Shahraki S. Comparison of efficacy of honey versus silver sulfadiazine and acetate mafenid in the treatment of burn wounds in piggies. Pak J Med Sci 2005;21(2):168-173.

95. Kumar A, Sharma VK, Singh HP, et al. Efficacy of some indigenous drugs in tissue repair in buffaloes. Indian Vet J 1993;70(1):42-44.

96. Gupta SK, Singh H, Varshney AC, et al. Therapeutic efficacy of honey in infected wounds in buffaloes. Indian J Anim Sci 1992;62(6):521-523.

97. Karabulut E, Durgun T. The use of honey in wound treatment. Indian Vet $J$ 2004;81(10):1108-1110.

98. Oladejo OW, Imosemi IO, Osuagwu FC, et al. A comparative study of the wound healing properties of honey and Ageratum conyzoides. Afr J Med Sci 2003;32(2):193-6.

99. Osuagwu FC, Oladejo OW, Imosemi IO, et al. Enhanced wound contraction in fresh wounds dressed with honey in wistar rats (Rattus Novergicus). West Afr J Med 2004;23(2):114-8.

100. Suguna L, Chandrakasan G, Thomas Joseph K. Influence of honey on collagen metabolism during wound healing in rats. J Clin Biochem Nutr 1992;13:7-12.

101. Suguna L, Chandrakasan G, Ramamoorthy $U$, et al. Influence of honey on biochemical and biophysical parameters of wounds in rats. J Clin Biochem Nutr 1993;14:91-99. 
102. Oryan A, Zaker SR. Effects of topical application of honey on cutaneous wound healing in rabbits. Journal of Veterinary Medicine Series A 1998;45(3):181-188. 103. Rao GVS, Selvaraj J, Senthil Ramanan R, et al. Efficacy of some indigenous medicines in wound healing in rats. Indian J Anim Sci 2003;73(6):652-653. 
Table 1. Randomised controlled trials that have been carried out on honey as a wound dressing

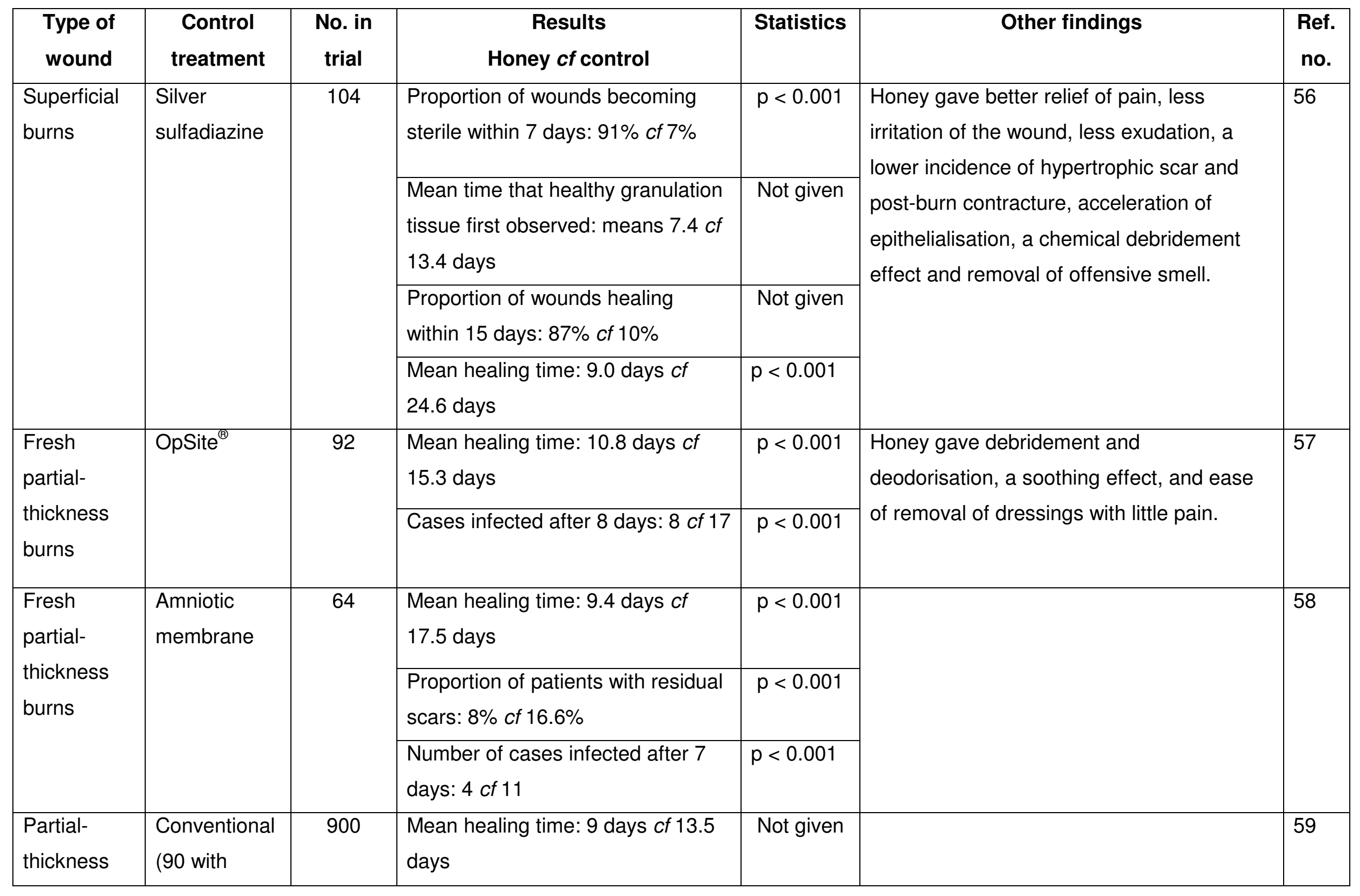




\begin{tabular}{|c|c|c|c|c|c|c|}
\hline & & & $\begin{array}{l}\text { Proportion of wounds infected: } \\
5.5 \% \text { cf } 12 \%\end{array}$ & Not given & & \\
\hline & & & $\begin{array}{l}\text { Proportion of cases resulting in } \\
\text { scars: } 6.2 \% \text { cf } 20 \%\end{array}$ & Not given & & \\
\hline \multirow{2}{*}{$\begin{array}{l}\text { Fresh } \\
\text { partial- } \\
\text { thickness } \\
\text { burns }\end{array}$} & \multirow[t]{2}{*}{$\begin{array}{l}\text { Boiled potato } \\
\text { peel }\end{array}$} & \multirow[t]{2}{*}{82} & $\begin{array}{l}\text { Mean healing time: } 10.4 \text { days } c f \\
16.2 \text { days }\end{array}$ & $p<0.001$ & & \multirow[t]{2}{*}{60} \\
\hline & & & $\begin{array}{l}\text { Proportion of those with positive } \\
\text { swab cultures becoming sterile } \\
\text { within } 7 \text { days: } 100 \% \text { cf } 0 \%\end{array}$ & $p<0.001$ & & \\
\hline \multirow[t]{2}{*}{$\begin{array}{l}\text { Superficial } \\
\text { burns }\end{array}$} & \multirow[t]{2}{*}{$\begin{array}{l}\text { Silver } \\
\text { sulfadiazine }\end{array}$} & \multirow[t]{2}{*}{50} & $\begin{array}{l}\text { Proportion showing epithelialisation } \\
\text { by } 7 \text { th day: } 84 \% \text { cf } 72 \% \text {; } \\
\text { by } 21 \text { st day: } 100 \% \text { cf } 84 \%\end{array}$ & $p<0.001$ & \multirow{2}{*}{$\begin{array}{l}\text { Honey gave early subsidence of acute } \\
\text { inflammatory changes, better control of } \\
\text { infection and quicker wound healing. } \\
\text { There was eschar in } 60 \% \text { of the cases } \\
\text { treated with silver sulfadiazine, none with } \\
\text { honey. } \\
\text { With silver sulfadiazine, } 4 \text { of the superficial } \\
\text { burns converted to deep burns requiring } \\
\text { skin grafting, none with honey. }\end{array}$} & \multirow[t]{2}{*}{50} \\
\hline & & & $\begin{array}{l}\text { Proportion showing evidence of } \\
\text { reparative activity (on histological } \\
\text { examination of biopsy samples): } \\
\text { on Day } 7: 80 \% \text { cf } 52 \% \\
\text { on Day } 21: 100 \% \text { cf } 84 \%\end{array}$ & $p<0.005$ & & \\
\hline \multirow{3}{*}{$\begin{array}{l}\text { Moderate } \\
\text { burns, half } \\
\text { of the total } \\
\text { burn area } \\
\text { being full- } \\
\text { thickness }\end{array}$} & \multirow{3}{*}{$\begin{array}{l}\text { Tangential } \\
\text { excision 3-6 } \\
\text { days post- } \\
\text { burn, then } \\
\text { skin grafting }\end{array}$} & \multirow[t]{3}{*}{50} & $\begin{array}{l}\text { Mean percentage blood volume } \\
\text { replaced: } 21 \% \text { cf } 35 \%\end{array}$ & $p<0.01$ & \multirow{3}{*}{$\begin{array}{l}\text { Skin grafting was required on only } 11 \text { of the } \\
25 \text { treated with honey cf all of the } \\
\text { tangentially excised group. }\end{array}$} & \multirow[t]{3}{*}{42} \\
\hline & & & $\begin{array}{l}\text { Mean period antibiotics needed: } 32 \\
\text { days } \text { cf } 16 \text { days }\end{array}$ & $p<0.001$ & & \\
\hline & & & $\begin{array}{l}\text { Proportion of swab cultures } \\
\text { positive: } 34 \% \text { cf } 10 \%\end{array}$ & $p<0.05$ & & \\
\hline
\end{tabular}




\begin{tabular}{|c|c|c|c|c|c|c|}
\hline & & & $\begin{array}{l}\text { Mean length of hospital stay: } 46 \\
\text { days } \text { cf } 21 \text { days }\end{array}$ & $p<0.001$ & & \\
\hline & & & $\begin{array}{l}\text { Proportion with excellent or good } \\
\text { wound appearance after } 3 \text { months: } \\
55 \% \text { cf } 92 \%\end{array}$ & $p<0.01$ & & \\
\hline \multirow{4}{*}{$\begin{array}{l}\text { Moderate } \\
\text { burns, } 1 / 6^{\text {th }} \\
\text { total burn } \\
\text { area being } \\
\text { full- } \\
\text { thickness }\end{array}$} & \multirow[t]{4}{*}{$\begin{array}{l}\text { Silver } \\
\text { sulfadiazine }\end{array}$} & \multirow[t]{4}{*}{100} & $\begin{array}{l}\text { Mean healing time: } 15.4 \text { days } c f \\
17.2 \text { days }\end{array}$ & $p<0.001$ & \multirow{4}{*}{$\begin{array}{l}\text { With honey, } 4 \text { required grafting cf } 11 \text { with } \\
\text { silver sulfadiazine, and there was one case } \\
\text { of contractures cf } 5 \text { with silver sulfadiazine. }\end{array}$} & \multirow[t]{4}{*}{51} \\
\hline & & & $\begin{array}{l}\text { Number of swab cultures positive } \\
\text { after } 7 \text { days: } 4 \text { (from } 44 \text { at start) cf } \\
42 \text { (from } 42 \text { at start) }\end{array}$ & $p<0.001$ & & \\
\hline & & & $\begin{array}{l}\text { Lipid peroxidation (a measure of } \\
\text { inflammation): } \\
\qquad \begin{array}{l}4.3 \text { cf } 5.3 \text { on day } 7 \\
3.8 \text { cf } 4.4 \text { on day } 14 \\
3.2 \text { cf } 4.1 \text { on day } 21\end{array}\end{array}$ & $\begin{array}{l}p<0.01 \\
p<0.01 \\
p<0.005\end{array}$ & & \\
\hline & & & $\begin{array}{l}\text { Mean length of hospital stay: } 22.0 \\
\text { days } \text { cf } 32.3 \text { days }\end{array}$ & $p<0.005$ & & \\
\hline \multirow[t]{3}{*}{$\begin{array}{l}\text { Paediatric } \\
\text { burns }\end{array}$} & \multirow[t]{3}{*}{$\begin{array}{l}\text { Silver } \\
\text { sulfadiazine }\end{array}$} & \multirow[t]{3}{*}{64} & $\begin{array}{l}\text { Mean healing time: } 11.0 \text { days } c f \\
16.1 \text { days }\end{array}$ & $p<0.001$ & \multirow{3}{*}{$\begin{array}{l}\text { There were } 2 \text { cases of contractures with } \\
\text { honey cf } 5 \text { with silver sulfadiazine. } \\
\text { Honey gave a decrease in oedema and } \\
\text { exudate, and no eschar. }\end{array}$} & \multirow[t]{3}{*}{61} \\
\hline & & & $\begin{array}{l}\text { Mean time to form healthy } \\
\text { granulation: } 6.7 \text { days cf } 12.8 \text { days }\end{array}$ & Not given & & \\
\hline & & & $\begin{array}{l}\text { Number of swab cultures positive } \\
\text { after } 7 \text { days: } 24 \text { (from } 25 \text { at start) cf } \\
21 \text { (from } 24 \text { at start) }\end{array}$ & $p<0.001$ & & \\
\hline
\end{tabular}




\begin{tabular}{|c|c|c|c|c|c|c|}
\hline $\begin{array}{l}\text { Superficial } \\
\text { burns }\end{array}$ & $\begin{array}{l}\text { Silver } \\
\text { sulfadiazine }\end{array}$ & 50 & $\begin{array}{l}100 \% \text { of cases healed in } 10 \text { days } \\
\text { cf } 70 \% \text { in } 15 \text { days }\end{array}$ & Not given & $\begin{array}{l}\text { Honey gave early subsidence of acute } \\
\text { inflammation, and better control of infection. } \\
\text { Honey reduced the period of hospital stay } \\
\text { and expenses by } 30 \% \text {. }\end{array}$ & 62 \\
\hline \multirow{5}{*}{$\begin{array}{l}\text { Severe } \\
\text { post- } \\
\text { operative } \\
\text { wound } \\
\text { infections } \\
\text { following } \\
\text { abdominal } \\
\text { surgey }\end{array}$} & \multirow{5}{*}{$\begin{array}{l}\text { Washing } \\
\text { wounds with } \\
70 \% \text { ethanol } \\
\text { then applying } \\
\text { povidone- } \\
\text { iodine }\end{array}$} & \multirow[t]{5}{*}{50} & $\begin{array}{l}\text { Mean time to get negative swab } \\
\text { cultures: } 6 \text { days of } 14.8 \text { days }\end{array}$ & $p<0.05$ & \multirow{5}{*}{$\begin{array}{l}\text { With honey there was mild wound } \\
\text { dehiscence in } 4 \text { cases, with no need for re- } \\
\text { suturing: in the control group there was } \\
\text { wound dehiscence in } 12 \text { cases, } 6 \text { requiring } \\
\text { re-suturing under general anaesthetic. }\end{array}$} & \multirow[t]{5}{*}{63} \\
\hline & & & $\begin{array}{l}\text { Mean number of days antibiotics } \\
\text { were required: } 6.88 \text { cf } 15.4\end{array}$ & $p<0.05$ & & \\
\hline & & & $\begin{array}{l}\text { Mean healing time: } 10.73 \text { days } c f \\
22.04 \text { days }\end{array}$ & $p<0.05$ & & \\
\hline & & & $\begin{array}{l}\text { Mean size of post-operative scars: } \\
3.62 \mathrm{~mm} \text { cf } 8.62 \mathrm{~mm}\end{array}$ & $p<0.05$ & & \\
\hline & & & $\begin{array}{l}\text { Mean period of hospitalisation } \\
\text { required: } 9.36 \text { days cf } 19.91 \text { days }\end{array}$ & $p<0.05$ & & \\
\hline \multirow{4}{*}{$\begin{array}{l}\text { Surgically } \\
\text { drained } \\
\text { pyomyositis } \\
\text { abscesses }\end{array}$} & \multirow{4}{*}{$\begin{array}{l}\text { EUSOL- } \\
\text { soaked } \\
\text { gauze }\end{array}$} & \multirow{4}{*}{$\begin{array}{c}32 \\
(43 \\
\text { wounds })\end{array}$} & $\begin{array}{l}\text { Proportion on Day } 7 \text { with clean } \\
\text { wounds: } 100 \% \text { cf } 65.5 \%\end{array}$ & $\mathrm{p}=0.007$ & & \multirow[t]{4}{*}{64} \\
\hline & & & $\begin{array}{l}\text { Proportion on Day } 7 \text { with } \\
\text { granulating wounds: } 100 \% \text { cf } 50 \%\end{array}$ & $p<0.001$ & & \\
\hline & & & $\begin{array}{l}\text { Proportion on Day } 7 \text { with } \\
\text { epithelialising wounds: } 86.9 \% \text { cf } \\
35 \%\end{array}$ & $\mathrm{p}=0.001$ & & \\
\hline & & & $\begin{array}{l}\text { Proportion on Day } 21 \text { with } \\
\text { complete epithelialisation: } 86.9 \% \text { cf } \\
55.0 \%\end{array}$ & $p=0.047$ & & \\
\hline
\end{tabular}




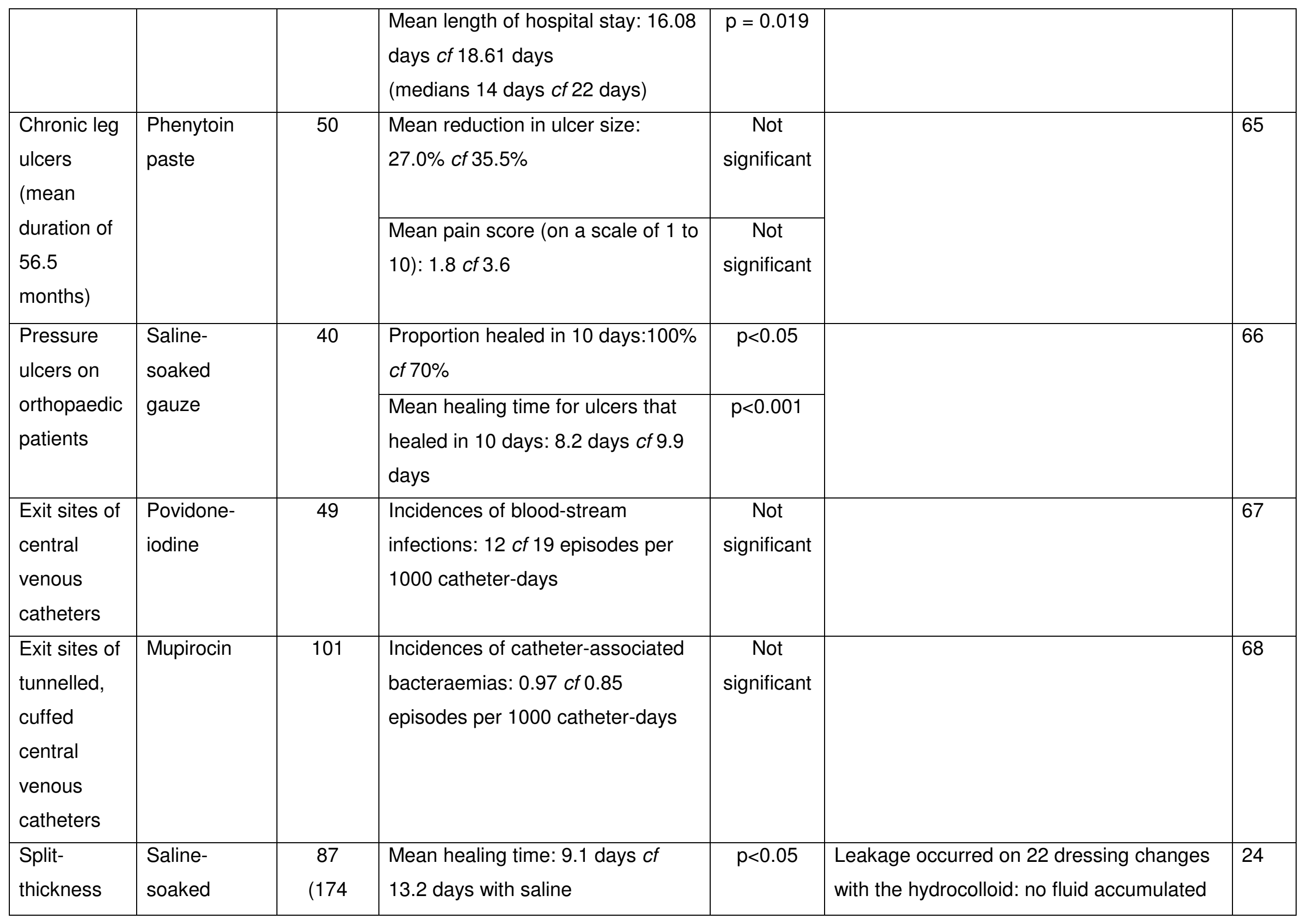




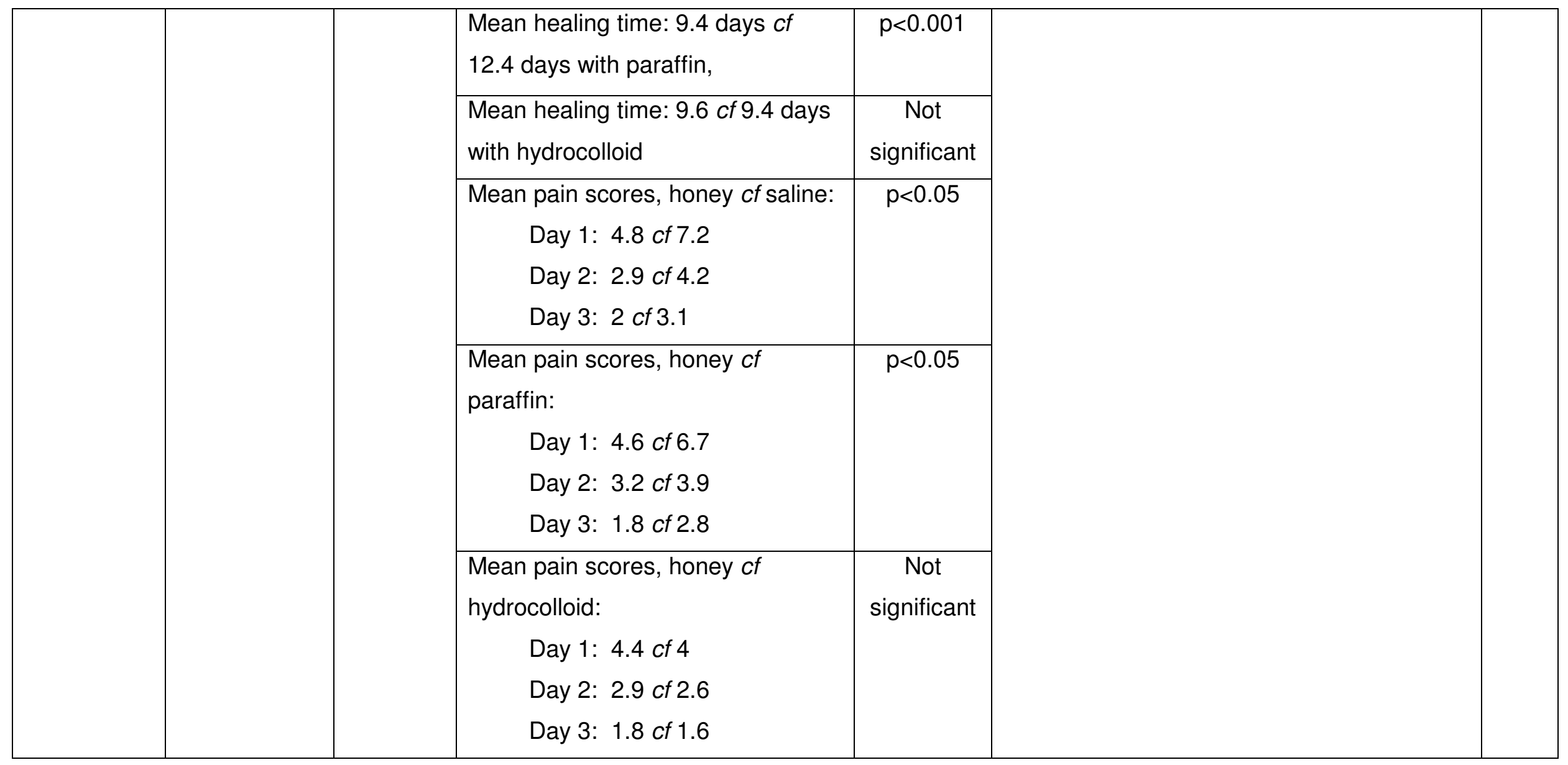


Table 2. Other types of clinical trials that have been carried out on honey as a wound dressing

\begin{tabular}{|c|c|c|c|c|c|c|}
\hline $\begin{array}{l}\text { Type of } \\
\text { wound }\end{array}$ & Form of trial & $\begin{array}{c}\text { No. in } \\
\text { trial }\end{array}$ & Results & Statistics & Other findings & $\begin{array}{l}\text { Ref. } \\
\text { no. }\end{array}$ \\
\hline $\begin{array}{c}\text { Disrupted } \\
\text { abdominal } \\
\text { wounds from } \\
\text { Caesarean } \\
\text { section }\end{array}$ & $\begin{array}{l}\text { Results from } 15 \text { patients } \\
\text { treated with honey } \\
\text { application and wound } \\
\text { approximation by } \\
\text { micropore tape were } \\
\text { compared retrospectively } \\
\text { with } 19 \text { similar cases who } \\
\text { had their dehisced } \\
\text { wounds cleaned with } \\
\text { hydrogen peroxide and } \\
\text { Dakin solution and packed } \\
\text { with saline-soaked gauze } \\
\text { prior to resuturing under } \\
\text { general anaesthesia. }\end{array}$ & $\begin{array}{c}15 c f \\
19\end{array}$ & $\begin{array}{l}\text { Period of hospitalisation } \\
\text { required: } 2 \text { - } 7 \text { days (mean 4.5) } \\
\text { with honey cf } 9 \text { - } 18 \text { days } \\
\text { (mean } 11.5 \text { ) with control }\end{array}$ & Not given & $\begin{array}{l}\text { With honey, } 11 \text { healed within } 7 \\
\text { days, the other } 4 \text { within } 2 \text { weeks. } \\
\text { With honey, slough and necrotic } \\
\text { tissue were replaced by } \\
\text { granulation and advancing } \\
\text { epithelialisation within } 2 \text { days, } \\
\text { wounds were made odourless } \\
\text { and sterile within } 1 \text { week, and no } \\
\text { re-suturing was required. }\end{array}$ & 69 \\
\hline
\end{tabular}




\begin{tabular}{|c|c|c|c|c|c|c|}
\hline $\begin{array}{l}\text { Fournier's } \\
\text { gangrene } \\
\text { (necrotising } \\
\text { fasciitis on } \\
\text { the scrotum) }\end{array}$ & $\begin{array}{l}20 \text { consecutive cases of } \\
\text { Fournier's gangrene } \\
\text { managed conservatively } \\
\text { with honey plus systemic } \\
\text { antibiotics (oral } \\
\text { amoxicillin/clavulanic acid } \\
\text { and metronidazole), were } \\
\text { compared with } 21 \text { cases } \\
\text { managed in the same } \\
\text { period by another } \\
\text { consultant, using surgical } \\
\text { debridement. }\end{array}$ & 41 & $\begin{array}{l}\text { With honey, within } 1 \text { week } \\
\text { malodour, oedema and } \\
\text { discharge had subsided, all } \\
\text { necrotic tissues had separated, } \\
\text { rapid epithelialisation was } \\
\text { occurring. } \\
\text { Within } 1 \text { week with honey all } \\
\text { swabs were negative: there was } \\
\text { no need to change from the } \\
\text { routine antibiotics to ones to } \\
\text { which the bacteria were found to } \\
\text { be sensitive, as was done with } \\
\text { the surgically debrided cases. }\end{array}$ & Not given & $\begin{array}{l}\text { A second operation for secondary } \\
\text { suturing was needed for all cases } \\
\text { surgically debrided, with plastic } \\
\text { reconstruction needed for two of } \\
\text { these With honey no surgery was } \\
\text { needed, and most healed with } \\
\text { very little or no scars. } \\
3 \text { deaths occurred in the } \\
\text { surgically treated group, none in } \\
\text { the honey-treated group. }\end{array}$ & 70 \\
\hline
\end{tabular}




\begin{tabular}{|c|c|c|c|c|c|c|}
\hline $\begin{array}{l}\text { Large } \\
\text { infected } \\
\text { surgical } \\
\text { wounds on } \\
\text { infants }\end{array}$ & $\begin{array}{l}\text { Treatment was crossed } \\
\text { over to honey dressings } \\
\text { after wounds had failed to } \\
\text { heal with treatment of at } \\
\text { least } 14 \text { days using } \\
\text { intravenous antibiotics } \\
\text { (vancomycin plus } \\
\text { cefotaxime, subsequently } \\
\text { changed according to } \\
\text { bacterial sensitivity), } \\
\text { fusidic acid ointment, and } \\
\text { wound cleaning with } \\
\text { aqueous } 0.05 \% \\
\text { chlorhexidine solution. }\end{array}$ & 9 & $\begin{array}{l}\text { After starting dressing with } \\
\text { honey a marked clinical } \\
\text { improvement was seen in all } \\
\text { cases after } 5 \text { days, and all } \\
\text { wounds were closed, clean and } \\
\text { sterile after } 21 \text { days. }\end{array}$ & Not given & $\begin{array}{l}\text { Six of the patients had systemic } \\
\text { antibiotic treatment discontinued } \\
\text { when treatment with honey } \\
\text { started. }\end{array}$ & 71 \\
\hline \multirow[t]{3}{*}{$\begin{array}{l}\text { Venous leg } \\
\text { ulcers, non- } \\
\text { healing after } \\
\text { at least } 12 \\
\text { weeks of } \\
\text { compression }\end{array}$} & \multirow[t]{3}{*}{$\begin{array}{l}\text { Treatment was crossed } \\
\text { over to honey dressings } \\
\text { used under compression } \\
\text { from standard treatment } \\
\text { for venous ulcers }\end{array}$} & \multirow[t]{3}{*}{40} & $\begin{array}{l}\text { Pain decreased from an } \\
\text { average McGill score of } 1.6 \text { to } \\
1.08 \text { in } 12 \text { weeks. } \\
\text { Linear decrease in pain with } \\
\text { time }\end{array}$ & $p<0.001$ & \multirow{3}{*}{$\begin{array}{l}\text { In the } 12 \text { week study period, } \\
\text { complete healing occurred in } 7 \\
\text { cases, with a significant reduction } \\
\text { in ulcer size for the rest (mean } \\
\text { reduction } 32 \% \text { ). } \\
\text { There was a high level of patient } \\
\text { satisfaction with honey dressings. }\end{array}$} & \multirow[t]{3}{*}{72} \\
\hline & & & $\begin{array}{l}\text { Decrease in pain correlated with } \\
\text { reduction in wound size }\end{array}$ & $p<0.05$ & & \\
\hline & & & $\begin{array}{l}\text { Decrease in pain correlated with } \\
\text { healing rate }\end{array}$ & $p<0.05$ & & \\
\hline
\end{tabular}




\begin{tabular}{|l|l|l|l|l|l|}
\hline & & & $\begin{array}{l}\text { The } 26 \text { malodorous wounds } \\
\text { decreased in odour mean score } \\
\text { (on a scale of } 1 \text { to 3) in two } \\
\text { weeks from } 1.58 \text { to } 0.69 .\end{array}$ & $p<0.001$ & \\
\hline Burns & $\begin{array}{l}\text { A review of all the burns } \\
\text { cases in a hospital over } \\
\text { the preceding 5 years }\end{array}$ & 156 & $\begin{array}{l}90.5 \% \text { of the cases were treated } \\
\text { with silver sulfadiazine, } 8.5 \% \\
\text { with honey: the outcomes were } \\
\text { similar. }\end{array}$ & Not given & \\
\hline
\end{tabular}


Table 3. Case studies on the use of honey as a wound dressing where a comparison with other treatments was conducted on multiple wounds within single cases

\begin{tabular}{|c|c|c|c|c|}
\hline Type of wounds & $\begin{array}{l}\text { Status of wounds before } \\
\text { using honey }\end{array}$ & Comparison & Results & $\begin{array}{l}\text { Ref. } \\
\text { no. }\end{array}$ \\
\hline $\begin{array}{l}\text { Multiple chronic leg } \\
\text { ulcers, on both legs }\end{array}$ & $\begin{array}{l}20 \text { year history of multiple } \\
\text { ulcers on the legs and feet } \\
\text { resulting from chronic venous } \\
\text { hypertension with secondary } \\
\text { lymphoedema }\end{array}$ & $\begin{array}{l}\text { The ulcers on one leg } \\
\text { were dressed with honey, } \\
\text { those on the other leg with } \\
\text { Aquacel, }\end{array}$ & $\begin{array}{l}\text { At the time of discharge } 10 \text { days later the ulcers } \\
\text { dressed with honey had a cleaner wound bed, signs } \\
\text { of infection had cleared and the green exudate had } \\
\text { ceased, whereas with the Aquacell there was } \\
\text { copious leakage of green fluid. }\end{array}$ & 44 \\
\hline $\begin{array}{l}\text { Multiple chronic leg } \\
\text { ulcers, on both legs }\end{array}$ & $\begin{array}{l}\text { Ulcers had been there for }>5 \\
\text { years. They had features of } \\
\text { stasis dermatitis. There was } \\
\text { no arterial disease. }\end{array}$ & $\begin{array}{l}\text { The ulcers on one leg } \\
\text { were dressed with honey, } \\
\text { those on the other leg } \\
\text { were debrided with } \\
\text { fibrinolysin (Elase } R \text { ) then } \\
\text { dressed with Sorbosan } R \text {. }\end{array}$ & $\begin{array}{l}\text { Initially healing was much more rapid with honey. } \\
\text { After I month both legs were healing well. }\end{array}$ & 74 \\
\hline $\begin{array}{l}\text { Broken-down wound } \\
\text { from abdominal } \\
\text { surgery }\end{array}$ & $\begin{array}{l}\text { Areas of dehiscence at each } \\
\text { end of the wound, of similar } \\
\text { appearance }\end{array}$ & $\begin{array}{l}\text { The dehiscence at one } \\
\text { end was dressed with } \\
\text { honey, on the other end } \\
\text { with Debrisan. }\end{array}$ & $\begin{array}{l}\text { Healing was complete in } 24 \text { days with honey, } 32 \\
\text { days with Debrisan. }\end{array}$ & 75 \\
\hline $\begin{array}{l}\text { Third-degree burns } \\
\text { to both arms }\end{array}$ & & $\begin{array}{l}\text { Burns on one arm were } \\
\text { dressed with honey, the } \\
\text { other arm with EUSOL. }\end{array}$ & $\begin{array}{l}\text { Granulation was "much nicer" with honey, reducing } \\
\text { time to skin grafting. }\end{array}$ & 76 \\
\hline
\end{tabular}


Table 4. Reports on the use of honey as a wound dressing: studies with multiple cases

\begin{tabular}{|c|c|c|c|c|}
\hline Type of wound & $\begin{array}{c}\text { Status of wounds before } \\
\text { using honey }\end{array}$ & $\begin{array}{l}\text { No. of } \\
\text { cases }\end{array}$ & Outcome from treatment with honey & $\begin{array}{l}\text { Ref. } \\
\text { no. }\end{array}$ \\
\hline $\begin{array}{l}16 \text { acute traumatic wounds, } 23 \\
\text { complicated surgical wounds } \\
\text { and } 21 \text { chronic non-responding } \\
\text { wounds }\end{array}$ & $\begin{array}{l}\text { The chronic non-responding } \\
\text { wounds had all been subjected } \\
\text { to other regimens before honey } \\
\text { dressings were used. }\end{array}$ & 60 & $\begin{array}{l}\text { One patient withdrew from the trial because the honey } \\
\text { was causing pain. Two wounds did not change. The rest } \\
\text { healed in a mean time of } 3 \text { weeks (range 1-28 weeks). } \\
\text { One patient was treated with silver sulfadiazine and } \\
\text { antibiotics instead of honey for one week because of an } \\
\text { infection with Staphylococcus aureus. } \\
\text { Advanced epithelialisation and a decrease in exudate, } \\
\text { oedema and wound odour were observed. }\end{array}$ & 77 \\
\hline $\begin{array}{l}\text { Recalcitrant wounds and } \\
\text { ulcers of varied aetiology, such } \\
\text { as Fournier's gangrene, burns, } \\
\text { cancrum oris, diabetic ulcers, } \\
\text { traumatic ulcers, decubitus } \\
\text { ulcers, sickle cell ulcers and } \\
\text { tropical ulcers }\end{array}$ & $\begin{array}{l}47 \text { of the patients had been } \\
\text { treated for } 1-24 \text { months with } \\
\text { conventional treatment (such as } \\
\text { Eusol toilet and dressings of } \\
\text { Acriflavine, Sofra-Tulle, or } \\
\text { Cicatrin, or systemic and topical } \\
\text { antibiotics) with no signs of } \\
\text { healing, or the wounds were } \\
\text { increasing in size. }\end{array}$ & 59 & $\begin{array}{l}\text { The } 51 \text { wounds with bacteria present became sterile within } \\
1 \text { week and the others remained sterile. In one of the } \\
\text { cases, a Buruli ulcer, treatment with honey was } \\
\text { discontinued after } 2 \text { weeks because the ulcer was rapidly } \\
\text { increasing in size. The } 58 \text { other cases "showed } \\
\text { remarkable improvement". Sloughs, necrotic and } \\
\text { gangrenous tissue separated so that they could be lifted } \\
\text { off painlessly, and were rapidly replaced with granulation } \\
\text { tissue and advancing epithelialisation. Surrounding } \\
\text { oedema subsided, weeping ulcers dehydrated, and foul- } \\
\text { smelling wounds were rendered odourless within } 1 \text { week. } \\
\text { Burn wounds treated early healed quickly, not becoming } \\
\text { colonised by bacteria. }\end{array}$ & 17 \\
\hline
\end{tabular}




\begin{tabular}{|c|c|c|c|c|}
\hline $\begin{array}{l}\text { Wounds from radical } \\
\text { vulvectomy with } \\
\text { lymphadectomy }\end{array}$ & Wounds had broken down & 12 & $\begin{array}{l}\text { Wounds became free from bacteria in 3-6 days. Complete } \\
\text { healing was achieved in 3-8 weeks. Clean healthy } \\
\text { granulation was achieved, requiring minimal surgical } \\
\text { debridement. Skin grafting was unnecessary. }\end{array}$ & 13 \\
\hline $\begin{array}{l}\text { Wounds of mixed aetiology: } \\
\text { surgical, accidental, infective, } \\
\text { trophic, and burns. The } \\
\text { average size of the wounds } \\
\text { was } 57 \mathrm{~cm}^{2} \text {. }\end{array}$ & $\begin{array}{l}\text { Half of the cases had been } \\
\text { treated with "the usual topical } \\
\text { measures" (an antiseptic) which } \\
\text { had failed. One third of the } \\
\text { wounds were purulent, the rest } \\
\text { were red with a whitish coat. }\end{array}$ & 40 & $\begin{array}{l}\text { Honey delimited the boundaries of the wounds and } \\
\text { cleansed the wounds rapidly to allow skin grafting. Of the } \\
33 \text { patients treated only with honey dressings, } 29 \text { were } \\
\text { healed successfully, with good quality healing, in an } \\
\text { average time of 5-6 weeks. Two of the four who did not } \\
\text { heal were suffering from immunodepression, one was } \\
\text { withdrawn from treatment with honey because of a painful } \\
\text { reaction to the honey, and one burn remained stationary } \\
\text { after a good initial response. }\end{array}$ & 78 \\
\hline $\begin{array}{l}\text { Septic wounds, chronic ulcers, } \\
\text { burns, pyogenic abscesses }\end{array}$ & $\begin{array}{l}6 \text { patients were diabetic, } 5 \text { with } \\
\text { a septic foot and } 1 \text { with an } \\
\text { abscess. }\end{array}$ & 11 & $\begin{array}{l}\text { Healing time was } 7-15 \text { days apart from one diabetic who } \\
\text { took } 56 \text { days and one, who was ill, in which there was no } \\
\text { improvement. Clean healthy granulation was achieved } \\
\text { which allowed skin grafting in } 14 \text { days ( } 30 \text { for one } \\
\text { diabetic), with prompt graft taking. }\end{array}$ & 18 \\
\hline $\begin{array}{l}\text { A variety of wounds, including } \\
\text { ulcers of various aetiologies, } \\
\text { pressure ulcers, burns, skin } \\
\text { tears and traumatic wounds }\end{array}$ & & 20 & $\begin{array}{l}\text { In } 80 \% \text { of cases the wound bed improved (it was cleaner, } \\
\text { with less slough and malodour, with movement along the } \\
\text { healing continuum). In } 20 \% \text { of cases there was no } \\
\text { improvement. } \\
65 \% \text { found honey dressings easy to apply, } 75 \% \text { found } \\
\text { them easy to remove, } 85 \% \text { found the dressings stayed in } \\
\text { place, } 65 \% \text { found them comfortable. }\end{array}$ & 79 \\
\hline
\end{tabular}




\begin{tabular}{|c|c|c|c|c|}
\hline $\begin{array}{l}\text { Surgical wounds, mostly } \\
\text { dehiscent or infected }\end{array}$ & $\begin{array}{l}\text { Pediatric patients receiving } \\
\text { chemotherapy, making wounds } \\
\text { hard to heal because of } \\
\text { profound immunosuppression }\end{array}$ & 16 & $\begin{array}{l}\text { Wounds became sterile within } 1-4 \text { days. The average } \\
\text { healing time was } 25 \text { days. Four patients undergoing } \\
\text { prolonged immunosuppression healed in an average time } \\
\text { of } 27 \text { days. Healing occurred without complication apart } \\
\text { from one small keloid. }\end{array}$ & 41 \\
\hline $\begin{array}{l}\text { Venous leg ulcers that had } \\
\text { undergone split-skin grafting }\end{array}$ & $\begin{array}{l}\text { Ulcers were of } 12 \text { months or } \\
\text { more duration, and were not } \\
\text { responding to normal treatment } \\
\text { such as compression. They } \\
\text { were of borderline suitability for } \\
\text { grafts. Five had conditions } \\
\text { characteristic of insufficient } \\
\text { tissue perfusion. }\end{array}$ & 6 & $\begin{array}{l}\text { The mean healing time was } 22 \text { days. There were no post- } \\
\text { operative infections or other complications. No re-grafting } \\
\text { or revision of grafts was needed. There was no recurrence } \\
\text { of the ulcers on follow-up (average of } 19 \text { months later). }\end{array}$ & 80 \\
\hline Fournier's gangrene & $\begin{array}{l}\text { Honey was used following } \\
\text { aggressive surgical debridement } \\
\text { and triple antibiotic therapy. }\end{array}$ & 38 & $\begin{array}{l}\text { Honey gave rapid healing changes in an average period of } \\
10 \text { days. }\end{array}$ & 81 \\
\hline $\begin{array}{l}\text { Gangrene in the genitals and } \\
\text { perineum }\end{array}$ & & 14 & $\begin{array}{l}\text { The mean time for the debriding action of the honey to } \\
\text { cleanse the wounds was } 5.2 \text { days, for granulation to be } \\
\text { seen was } 9.4 \text { days, and for complete healing was } 28.7 \\
\text { days. }\end{array}$ & 82 \\
\hline
\end{tabular}


Table 5. Reports on the use of honey as a wound dressing: studies of single cases

\begin{tabular}{|c|c|c|c|}
\hline Type of wound & Status of wound before using honey & Outcome from treatment with honey & $\begin{array}{l}\text { Ref. } \\
\text { no. }\end{array}$ \\
\hline $\begin{array}{l}\text { Bilateral leg ulcers of mixed } \\
\text { aetiology }\end{array}$ & $\begin{array}{l}88 \text { year old patient with marked lower } \\
\text { leg oedema and peri-wound maceration } \\
\text { of skin }\end{array}$ & $\begin{array}{l}\text { Within } 4 \text { weeks there was a dramatic improvement in the } \\
\text { maceration, and the ulcer beds were much healthier. }{ }^{*}\end{array}$ & 79 \\
\hline Venous ulcer & $\begin{array}{l}\text { Five-year history of intermittent infected } \\
\text { venous ulcers. The ulcer was inflamed, } \\
\text { with necrosis, oedema and exudate. } \\
\text { There had been no improvement with } 4 \\
\text { weeks of treatment with hydrogel. }\end{array}$ & $\begin{array}{l}\text { The exudate was decreased, so a compression stocking } \\
\text { could then be used. The necrosis was debrided in } 10 \text { days. } \\
\text { Complete healing was achieved in } 28 \text { weeks. The skin } \\
\text { integrity had been maintained } 18 \text { months later. }\end{array}$ & 49 \\
\hline Extensive leg ulcers & $\begin{array}{l}75 \text { year old patient. Ulcers had } \\
\text { increased in size over the past } 4 \text { years } \\
\text { without signs of permanent healing } \\
\text { despite ongoing attention. }\end{array}$ & $\begin{array}{l}\text { The foul smell disappeared. Granulation and islands of } \\
\text { epithelialisation were seen within } 3 \text { weeks. }{ }^{*}\end{array}$ & 77 \\
\hline Leg ulcers & $\begin{array}{l}85 \text { year old patient with a history of } \\
\text { numerous small sloughy leg ulcers not } \\
\text { reducing in size despite 3-layer } \\
\text { compression bandaging. There were } \\
\text { calcium deposits subcutaneously and in } \\
\text { the ulcer beds with associated chronic } \\
\text { inflammation. The deposits had been } \\
\text { removed by sharp debridement every } 3 \\
\text { months. }\end{array}$ & $\begin{array}{l}\text { After } 2 \text { weeks, atraumatic removal of the calcium deposits } \\
\text { was occurring. This continued with further use of honey, with } \\
\text { reduction in wound size, slough and inflammation. }{ }^{*}\end{array}$ & 83 \\
\hline
\end{tabular}




\begin{tabular}{|c|c|c|c|}
\hline $\begin{array}{l}\text { Hydroxyurea-induced leg ulcer } \\
\text { on an immunosuppressed } \\
\text { patient }\end{array}$ & $\begin{array}{l}\text { No change in the ulcer had occurred } \\
\text { over three months of treatment with a } \\
\text { range of topical therapies. It was } \\
\text { sloughy, and MRSA was present. }\end{array}$ & $\begin{array}{l}\text { MRSA was cleared in } 14 \text { days. Healing was complete within } \\
21 \text { days. Treatment with hydroxyurea and cyclosporin } \\
\text { continued through this period. }\end{array}$ & 38 \\
\hline Multiple bilateral venous ulcers & $\begin{array}{l}25 \text { year history of venous ulceration } \\
\text { with recurrent infections. Ulcers were } \\
\text { deep, highly exuding, sloughy and } \\
\text { malodorous. There was widespread } \\
\text { varicose eczema in the region of the } \\
\text { ulcers }\end{array}$ & $\begin{array}{l}\text { The malodour was removed within } 1 \text { day. After } 10 \text { days all } \\
\text { signs of eczema had gone. But when compression } \\
\text { bandaging was commenced there was within two days } \\
\text { another outbreak of bacterial infection.* }\end{array}$ & 84 \\
\hline $\begin{array}{l}\text { Mixed arterial/venous ulcers on } \\
\text { calf and median malleolus }\end{array}$ & $\begin{array}{l}\text { The ulcers, on an } 80 \text { year old patient, } \\
\text { had occasionally shown signs of } \\
\text { improvement in the past but they had } \\
\text { never healed. Sharp debridement and } \\
\text { removal of calcification was carried out } \\
\text { before starting treatment with honey. }\end{array}$ & $\begin{array}{l}\text { After } 4 \text { weeks there was a } 23.6 \% \text { reduction in area of the } \\
\text { large ulcer on the calf, and full epithelialisation of the small } \\
\text { ulcer on the malleolus. }{ }^{*}\end{array}$ & 48 \\
\hline
\end{tabular}




\begin{tabular}{|c|c|c|c|}
\hline Extensive venous ulcers & $\begin{array}{l}\text { The ulcers, on an } 80 \text { year old patient, } \\
\text { were of } 2 \frac{1}{2} \text { years duration, with } \\
\text { compression being used. Recurrent } \\
\text { infections had occurred, soon after } \\
\text { each course of antibiotics had finished, } \\
\text { that silver dressings did not prevent. } \\
\text { The ulcers on one leg had got cellulitic, } \\
\text { very wet, painful, and covered with soft } \\
\text { necrotic tissue. They were debrided } \\
\text { before starting treatment with honey. } \\
\text { The ulcer on the other leg was clean } \\
\text { but static and over-granulating }\end{array}$ & $\begin{array}{l}\text { Over the next } 6 \text { weeks no further infection occurred. (A low } \\
\text { dose of Flucoxacillin was used for the first } 3 \text { weeks.) Then, } \\
\text { coinciding with compression being started, infection recurred } \\
\text { in the wet ulcers. }{ }^{*} \text { The over-granulating static ulcer on the } \\
\text { other leg was healed, level with the skin, after } 3 \text { weeks } \\
\text { treatment with honey. }\end{array}$ & 48 \\
\hline Venous ulcer & $\begin{array}{l}\text { Painful, sloughy, highly exuding, } \\
\text { malodorous. Initial debridement was } \\
\text { done with maggots. }\end{array}$ & Complete deodorisation was achieved within 24 hours. ${ }^{*}$ & 48 \\
\hline $\begin{array}{l}\text { Diabetic foot ulcers, } 8 \times 5 \mathrm{~cm} \\
\text { and } 3 \times 3 \mathrm{~cm}\end{array}$ & $\begin{array}{l}79 \text { year old patient. The ulcers } \\
\text { remained unhealed after } 14 \text { months } \\
\text { treatment with an orthotic device, } \\
\text { antibiotics, topical therapies by a wound } \\
\text { care expert and four lots of surgery. } \\
\text { MRSA, VRE and Pseudomonas were } \\
\text { present in wound tissue. }\end{array}$ & $\begin{array}{l}\text { The ulcers were granulating within } 2 \text { weeks, and healed } \\
\text { within } 6 \text { and } 12 \text { months. There had been no recurrence } 2 \\
\text { years later. }\end{array}$ & 40 \\
\hline
\end{tabular}




\begin{tabular}{|c|c|c|c|}
\hline $\begin{array}{l}\text { Pressure ulcer on ankle, } 4 \mathrm{x} \\
2.5 \mathrm{~cm} \text {, down to tendon }\end{array}$ & $\begin{array}{l}83 \text { year old patient. There was no } \\
\text { commencement of healing when } \\
\text { treated with SoloSite and hydrocolloids } \\
\text { for } 3 \text { weeks. The ulcer was highly } \\
\text { exudative, with a strong malodour, and } \\
\text { painful. }\end{array}$ & $\begin{array}{l}\text { After } 13 \text { days there was much less malodour and less slough. } \\
\text { The ulcer was healed in } 11 \text { weeks. }\end{array}$ & 85 \\
\hline Sacral pressure ulcer & $\begin{array}{l}84 \text { year old patient. The } 5.5 \times 5 \mathrm{~cm} \\
\text { ulcer had an area of necrosis } 2 \times 1 \mathrm{~cm} \text {. } \\
\text { The surrounding area was red and } \\
\text { painful. There had been no } \\
\text { improvement after } 4 \text { weeks of debriding } \\
\text { treatment with SoloSite then a } \\
\text { hydrocolloid then Solugel. }\end{array}$ & $\begin{array}{l}\text { The ulcer was debrided after } 2 \text { weeks, and was healed by } 8 \\
\text { weeks, almost without scarring. }\end{array}$ & 85 \\
\hline Sacral pressure ulcer & $\begin{array}{l}\text { The ulcer was } 15-20 \mathrm{~cm} \text { in size, } \\
\text { exposing bone. }\end{array}$ & $\begin{array}{l}\text { The ulcer became closed, without surgery, after } 21 \text { days, and } \\
\text { completely re-epithelialised in } 10 \text { weeks }\end{array}$ & 19 \\
\hline Pressure ulcers & $\begin{array}{l}\text { There was one } 10 \times 5 \mathrm{~cm} \text { ulcer, on the } \\
\text { buttocks, with a deep centre, and two } \\
\text { smaller ulcers. There was some } \\
\text { discharge from the ulcers. }\end{array}$ & $\begin{array}{l}\text { Granulation was seen after } 7 \text { days. The smaller ulcers } \\
\text { completely healed in } 4 \text { weeks, the larger one in } 8 \text { weeks. }\end{array}$ & 12 \\
\hline Pressure ulcers & $\begin{array}{l}\text { The ulcer on one hip was deep. The } \\
\text { large ulcer on the other hip and the } \\
\text { linking ulcers in the sacral region had } \\
\text { black slough. All ulcers were } \\
\text { discharging and becoming offensive. } \\
\text { The patient had disseminated sclerosis } \\
\text { and was weak and ill. }\end{array}$ & $\begin{array}{l}\text { Within } 6 \text { weeks all slough had separated, there was no } \\
\text { purulent discharge or malodour, and healthy granulation was } \\
\text { seen at the edges of the ulcers. }\end{array}$ & 12 \\
\hline
\end{tabular}




\begin{tabular}{|c|c|c|c|}
\hline Broken area of skin on calf & $\begin{array}{l}\text { The } 6 \times 2 \mathrm{~cm} \text { wound, on an obese } \\
\text { patient, was colonised, sloughy, with } \\
\text { minimal exudate, and with a macerated } \\
\text { peri-wound area }\end{array}$ & Healed in 4 weeks & 86 \\
\hline $\begin{array}{l}\text { Unhealed biopsy wound in } \\
\text { groin }\end{array}$ & $\begin{array}{l}\text { Immunocompromised patient, with } \\
\text { lymphoma, undergoing chemotherapy: } \\
\text { wound at risk of becoming infected }\end{array}$ & The wound was completely healed in 4 weeks. & 39 \\
\hline $\begin{array}{l}\text { Non-healing split-thickness } \\
\text { skin graft donor site }\end{array}$ & $\begin{array}{l}\text { The donor site was not healing } 9 \\
\text { months after a skin graft had been } \\
\text { harvested. There was some over- } \\
\text { granulation, and moderate exudate. }\end{array}$ & $\begin{array}{l}\text { Healing was evident after } 2 \text { weeks, with exudate and pain } \\
\text { reduced. Complete healing was achieved in } 4 \text { weeks. }\end{array}$ & 87 \\
\hline $\begin{array}{l}\text { Abscess following orthopaedic } \\
\text { surgery }\end{array}$ & $\begin{array}{l}\text { The wound was unhealed } 9 \text { months } \\
\text { after the surgery, despite courses of } \\
\text { antibiotics and many types of dressings } \\
\text { being tried. The abscess was } \\
\text { recalcitrant, with a small amount of } \\
\text { slough. }\end{array}$ & $\begin{array}{l}\text { After } 4 \text { weeks the surrounding redness was settling and there } \\
\text { was some debridement. After a further } 20 \text { weeks the wound } \\
\text { was the size of a pin-head, with no redness. }\end{array}$ & 87 \\
\hline $\begin{array}{l}\text { Lymphorrhoea in the groin } \\
\text { resulting from a voluminous } \\
\text { lymphocele following surgery } \\
\text { on the iliac artery }\end{array}$ & $\begin{array}{l}\text { The patient refused the further surgery } \\
\text { that was advised. }\end{array}$ & $\begin{array}{l}\text { Placing honey in the inguinal cavity daily reduced the liquid } \\
\text { discharge to a minor amount within a few days, with a } \\
\text { notable reduction in the size of the cavity. No discharge was } \\
\text { occurring after } 11 \text { days.* }\end{array}$ & 88 \\
\hline $\begin{array}{l}\text { Cavity wounds from broken- } \\
\text { down haematomas, also } \\
\text { infected split-thickness skin } \\
\text { graft donor site }\end{array}$ & $\begin{array}{l}\text { There were two large wounds on the } \\
\text { lower leg of an obese patient with } \\
\text { chronic lymphoedema, on which skin } \\
\text { grafting had failed. MRSA was present. }\end{array}$ & $\begin{array}{l}\text { The MRSA was eliminated, and complete healing was } \\
\text { achieved in } 8 \text { weeks without further grafting, the donor sites } \\
\text { healing first. Elimination of the offensive wound odour was } \\
\text { also noted. }\end{array}$ & 37 \\
\hline
\end{tabular}




\begin{tabular}{|c|c|c|c|}
\hline $\begin{array}{l}\text { Broken-down wound from } \\
\text { amputation of toe }\end{array}$ & $\begin{array}{l}\text { Amputation was because of gangrene } \\
\text { in the big toe of an } 83 \text { year old patient. } \\
\text { No improvement seen in the wound } \\
\text { after } 6 \text { weeks of EUSOL and paraffin } \\
\text { dressings. A hard crust, } 2.5 \times 4 \mathrm{~cm} \text {, } \\
\text { covered the wound. }\end{array}$ & $\begin{array}{l}\text { The crust started to separate and granulation was seen after } \\
7 \text { days. By } 2 \text { weeks a lot of the crust had been removed and } \\
\text { improvement in granulation had occurred.* }\end{array}$ & 12 \\
\hline $\begin{array}{l}\text { Recalcitrant wound in the } \\
\text { axilla, from surgical treatment } \\
\text { of hidradenitis suppurativa }\end{array}$ & $\begin{array}{l}\text { The wound had failed to heal for } 36 \\
\text { months despite trying a wide range of } \\
\text { therapeutic dressings and systemic and } \\
\text { topical antimicrobial agents and three } \\
\text { attempts at treatment by surgery. }\end{array}$ & $\begin{array}{l}\text { There was removal of bacteria and a noticeable improvement } \\
\text { in the wound in one week, and complete healing in one } \\
\text { month. }\end{array}$ & 89 \\
\hline $\begin{array}{l}\text { Grossly infected wound from } \\
\text { Caesarian section }\end{array}$ & $\begin{array}{l}\text { There was pus pouring from an open } \\
12 \mathrm{~cm} \text { wound. Infection had not } \\
\text { responded to several courses of } \\
\text { antibiotics. }\end{array}$ & $\begin{array}{l}\text { The wound was clean and granulating after } 7 \text { days, and } \\
\text { completely healed in } 2 \text { weeks. }\end{array}$ & 19 \\
\hline $\begin{array}{l}\text { Broken-down surgical wound } \\
\text { after breast reduction }\end{array}$ & $\begin{array}{l}\text { Wound break-down started } 6 \text { weeks } \\
\text { after surgery and deteriorated over the } \\
\text { following } 2 \text { weeks. There was some } \\
\text { granulation and some small areas of } \\
\text { necrosis. The exudate was distressing. }\end{array}$ & $\begin{array}{l}\text { After } 2 \text { weeks the necrosis and slough had cleared, the } \\
\text { malodour had gone, there was healthy granulation, and the } \\
\text { exudate was manageable. There was complete healing in } 13 \\
\text { weeks. }\end{array}$ & 90 \\
\hline Non-healing surgical wound & $\begin{array}{l}\text { The wound was not healing after } 4 \\
\text { weeks of daily dressing with calcium } \\
\text { alginate. }\end{array}$ & Complete healing was achieved in 6 weeks. & 77 \\
\hline Non-healing traumatic wound & $\begin{array}{l}\text { The } 4 \times 4 \mathrm{~cm} \text { wound, on the lower arm, } \\
\text { was clean but had no signs of } \\
\text { granulation (no capillary buds were } \\
\text { present). }\end{array}$ & $\begin{array}{l}\text { Granulation and epithelialisation were visible within } 1 \text { week, } \\
\text { and complete healing was achieved in } 6 \text { weeks. }\end{array}$ & 37 \\
\hline
\end{tabular}




\begin{tabular}{|c|c|c|c|}
\hline $\begin{array}{l}\text { Extensive infected skin lesions } \\
\text { resulting from meningococcal } \\
\text { septicaemia }\end{array}$ & $\begin{array}{l}\text { These lesions had a heavy growth of } \\
\text { Pseudomonas, Staphylococcus aureus } \\
\text { and Enterococcus, and had remained } \\
\text { non-healing for } 8 \text { months despite a } \\
\text { wide range of treatments being tried. } \\
\text { Additional lesions had resulted from } \\
\text { graft donor sites becoming infected. }\end{array}$ & $\begin{array}{l}\text { Within a few days, signs of epithelialisation were seen, skin } \\
\text { grafting became possible as the pathogens were cleared, } \\
\text { and complete healing was achieved within } 10 \text { weeks. }\end{array}$ & 91 \\
\hline $\begin{array}{l}\text { Ulcer between breasts from } \\
\text { radiation necrosis }\end{array}$ & $\begin{array}{l}\text { The wound had initially appeared } 13 \\
\text { months after mastectomy and } \\
\text { radiotherapy and had then healed } 13 \\
\text { months after that, then had re-ulcerated } \\
\text { a few months later and enlarged to } 4 \mathrm{x} \\
3 \mathrm{~cm} \text { with necrotic bone and costal } \\
\text { cartilage at its base. The wound was } \\
\text { painful, with thick, offensive pus } \\
\text { exuding. The peri-wound area was sore } \\
\text { and excoriated. }\end{array}$ & Complete healing occurred in 10 months. & 90 \\
\hline $\begin{array}{l}\text { Spontaneously erupted } \\
\text { abscess (of unknown cause) } \\
\text { on cheek }\end{array}$ & $\begin{array}{l}\text { After surgical drainage and antibiotics } \\
\text { the lump arose again. }\end{array}$ & $\begin{array}{l}\text { After } 3 \text { lots of honey dressing of less than } 24 \text { hours each, on } \\
\text { unbroken skin, the lump had reduced in size.* }\end{array}$ & 48 \\
\hline Burn on upper arm & $\begin{array}{l}88 \text { year old patient. The burn had dried } \\
\text { out, but after } 1 \frac{1}{2} \text { weeks of treatment } \\
\text { with hydrogel the eschar was still dry, } \\
\text { so the wound was tight and painful }\end{array}$ & $\begin{array}{l}\text { The eschar was softened within } 1 \text { week, so the wound } \\
\text { became less painful. Debriding was occurring within } 3 \text { weeks } \\
\text { and was complete within } 10 \text { weeks, with extensive } \\
\text { epithelialisation.* }\end{array}$ & 79 \\
\hline
\end{tabular}

* Details of subsequent progress were not reported 
Table 6. Animal experiments carried out on the use of honey as a wound dressing

\begin{tabular}{|c|c|c|c|c|c|c|c|}
\hline $\begin{array}{l}\text { Type of } \\
\text { wound }\end{array}$ & $\begin{array}{l}\text { Control } \\
\text { treatment }\end{array}$ & $\begin{array}{l}\text { Species } \\
\text { of animal }\end{array}$ & $\begin{array}{c}\text { No. in } \\
\text { trial }\end{array}$ & Results & Statistics & Other findings & $\begin{array}{l}\text { Ref. } \\
\text { no. }\end{array}$ \\
\hline \multirow{2}{*}{$\begin{array}{l}\text { Deep dermal } \\
\text { burns }(6.7 \times 6.7 \\
\mathrm{cm}) \text { made with a } \\
170^{\circ} \mathrm{C} \text { brass } \\
\text { block }\end{array}$} & \multirow[t]{2}{*}{$\begin{array}{l}\text { Silver } \\
\text { sulfadiazine: } \\
\text { also sugar }\end{array}$} & \multirow[t]{2}{*}{$\begin{array}{l}\text { Yorkshire } \\
\text { pigs }\end{array}$} & \multirow[t]{2}{*}{$\begin{array}{c}3 \\
(36 \\
\text { wounds })\end{array}$} & $\begin{array}{l}\text { Complete epithelialisation achieved } \\
\text { within } 21 \text { days with both honey and } \\
\text { sugar, cf } 28 \text { - } 35 \text { days with silver } \\
\text { sulfadiazine }\end{array}$ & Not given & & \multirow[t]{2}{*}{92} \\
\hline & & & & $\begin{array}{l}\text { Histological examination revealed less } \\
\text { inflammation in wounds treated with } \\
\text { honey than in those treated with sugar } \\
\text { and with silver sulfadiazine, and a } \\
\text { more advanced stage of healing. }\end{array}$ & Not given & & \\
\hline \multirow{2}{*}{$\begin{array}{l}\text { Dermal burns }(1.3 \\
\times 3 \mathrm{~cm}) \text { made } \\
\text { with a } 170^{\circ} \mathrm{C} \\
\text { brass block }\end{array}$} & \multirow{2}{*}{$\begin{array}{l}\text { Silver } \\
\text { sulfadiazine: } \\
\text { also } \\
\text { untreated } \\
\text { (other than a } \\
\text { daily saline } \\
\text { rinse) }\end{array}$} & \multirow[t]{2}{*}{ Pigs } & \multirow[t]{2}{*}{$\begin{array}{c}2 \\
(27 \\
\text { wounds })\end{array}$} & $\begin{array}{l}\text { First granulation was observed } \\
\text { (histologically) after } 5 \text { days with } \\
\text { honey, } 10 \text { days with the controls. }\end{array}$ & Not given & & \multirow[t]{2}{*}{93} \\
\hline & & & & $\begin{array}{l}\text { Less oedema and inflammation was } \\
\text { observed (histologically) with honey } \\
\text { than with the controls. }\end{array}$ & Not given & & \\
\hline $\begin{array}{l}\text { Third-degree } \\
\text { dermal burns } \\
\text { (made with } \\
\text { steam), } 8.5 \mathrm{~cm}^{2} \text {, } \\
\text { inoculated with }\end{array}$ & $\begin{array}{l}\text { Silver } \\
\text { sulfadiazine : } \\
\text { also acetate } \\
\text { mafenid }\end{array}$ & Piglets & 60 & $\begin{array}{l}\text { After } 30 \text { days, the mean reduction in } \\
\text { wound area was } 62 \% \text { with honey cf } \\
29 \% \text { with silver sulfadiazine and } 22 \% \\
\text { with acetate mafenid. }\end{array}$ & $\begin{array}{l}\mathrm{p}=0.000 \\
\text { for honey } \\
\text { cf the } \\
\text { other } \\
\text { treatments }\end{array}$ & & 94 \\
\hline
\end{tabular}




\begin{tabular}{|c|c|c|c|c|c|c|c|}
\hline & & & & $\begin{array}{l}\text { After } 10 \text { days, the proportion of } \\
\text { wounds with good granulation } \\
\text { covering the major part, suitable for } \\
\text { grafting, was } 90 \% \text { with honey cf } 44 \% \\
\text { with silver sulfadiazine and } 35 \% \text { with } \\
\text { acetate mafenid. }\end{array}$ & $\begin{array}{l}\mathrm{p}<0.003 \\
\text { for honey } \\
\text { cf the } \\
\text { other } \\
\text { treatments }\end{array}$ & & \\
\hline & & & & $\begin{array}{l}\text { The proportion of biopsy samples, } \\
\text { taken after } 10 \text { days, giving positive } \\
\text { microbial cultures was } 20 \% \text { with } \\
\text { honey cf } 100 \% \text { with silver } \\
\text { sulfadiazine and } 95 \% \text { with acetate } \\
\text { mafenid. }\end{array}$ & $\begin{array}{l}p=0.000 \\
\text { for honey } \\
\text { cf the } \\
\text { other } \\
\text { treatments }\end{array}$ & & \\
\hline \multirow[t]{2}{*}{$\begin{array}{l}\text { Superficial burns, } \\
\text { created on the } \\
\text { skin with a red- } \\
\text { hot pin }\left(15 \mathrm{~mm}^{2}\right)\end{array}$} & \multirow[t]{2}{*}{$\begin{array}{l}\text { No treatment: } \\
\text { also, solution } \\
\text { of sugars as } \\
\text { in honey }\end{array}$} & \multirow[t]{2}{*}{ Rats } & \multirow[t]{2}{*}{$\begin{array}{c}60 \\
(120 \\
\text { wounds })\end{array}$} & $\begin{array}{l}\text { The mean time to complete healing } \\
\text { was } 20.4 \text { days with honey cf } 30.3 \\
\text { days with no treatment. }\end{array}$ & $p<0.01$ & \multirow{2}{*}{$\begin{array}{l}\text { Healing was seen } \\
\text { histologically to be } \\
\text { more active and } \\
\text { advanced with honey, } \\
\text { and honey was also } \\
\text { clearly seen to give } \\
\text { attenuation of } \\
\text { inflammation and } \\
\text { exudation, and less } \\
\text { serious necrosis. }\end{array}$} & \multirow[t]{2}{*}{16} \\
\hline & & & & $\begin{array}{l}\text { The mean time to complete healing } \\
\text { was } 20.4 \text { days with honey cf } 28.5 \\
\text { days with sugar. }\end{array}$ & $p<0.01$ & & \\
\hline
\end{tabular}




\begin{tabular}{|c|c|c|c|c|c|c|c|}
\hline $\begin{array}{l}\text { Wounds created } \\
\text { by cutting away } 2 \\
\times 4 \mathrm{~cm} \text { pieces of } \\
\text { skin on the back }\end{array}$ & $\begin{array}{l}\text { Nitrofurazone } \\
\text {; also } \\
\text { sterilised } \\
\text { petrolatum }\end{array}$ & $\begin{array}{l}\text { Buffalo } \\
\text { calves }\end{array}$ & $\begin{array}{c}6 \\
(24 \\
\text { wounds })\end{array}$ & $\begin{array}{l}\text { Granulation, scar formation, and } \\
\text { complete healing occurred faster with } \\
\text { honey, with more proliferation of } \\
\text { fibroblasts and angioblasts. }\end{array}$ & Not given & $\begin{array}{l}\text { Attenuation of } \\
\text { inflammation by } \\
\text { honey was also seen } \\
\text { (by histological } \\
\text { observation). }\end{array}$ & 95 \\
\hline $\begin{array}{l}\text { Wounds created } \\
\text { by cutting away } 2 \\
\times 4 \mathrm{~cm} \text { pieces of } \\
\text { skin on the back, } \\
\text { infected by } \\
\text { subcutaneous } \\
\text { injection of } \\
\text { Staphylococcus } \\
\text { aureus two days } \\
\text { prior to wounding }\end{array}$ & $\begin{array}{l}\text { Ampicillin } \\
\text { ointment: } \\
\text { also saline }\end{array}$ & $\begin{array}{l}\text { Buffalo } \\
\text { calves }\end{array}$ & $\begin{array}{c}9 \\
(90 \\
\text { wounds })\end{array}$ & $\begin{array}{l}\text { Honey gave the fastest rate of healing } \\
\text { compared with the other treatments, } \\
\text { also (observed histologically) the most } \\
\text { rapid fibroblastic and angioblastic } \\
\text { activity in the wounds and the fastest } \\
\text { epithelialisation. }\end{array}$ & Not given & $\begin{array}{l}\text { Attenuation of } \\
\text { inflammation by } \\
\text { honey was also seen } \\
\text { (by histological } \\
\text { observation). }\end{array}$ & 96 \\
\hline \multirow[t]{2}{*}{$\begin{array}{l}\text { Wounds created } \\
\text { by excising skin } \\
(1 \times 1 \mathrm{~cm})\end{array}$} & \multirow[t]{2}{*}{ Saline } & \multirow[t]{2}{*}{ Mice } & \multirow[t]{2}{*}{24} & $\begin{array}{l}\text { Histological examination showed that } \\
\text { the thickness of granulation tissue } \\
\text { was greater with honey. }\end{array}$ & $p<0.001$ & & \multirow[t]{2}{*}{20} \\
\hline & & & & $\begin{array}{l}\text { Histological examination showed that } \\
\text { the distance of epithelialisation from } \\
\text { the edge of the wound was greater } \\
\text { with honey. }\end{array}$ & $\mathrm{p}<0.001$ & & \\
\hline
\end{tabular}




\begin{tabular}{|c|c|c|c|c|c|c|c|}
\hline $\begin{array}{l}\text { Wounds created } \\
\text { by excising skin } \\
(1 \times 1 \mathrm{~cm})\end{array}$ & Saline & Rats & $\begin{array}{c}15 \\
(30 \\
\text { wounds })\end{array}$ & $\begin{array}{l}\text { The area of the wound }\left(\mathrm{mm}^{2}\right) \text { with the } \\
\text { honey treatment } \text { cf the area with } \\
\text { saline was: } \\
\text { after } 4 \text { days: } 47.5 \text { cf } 71.4 \\
\text { after } 8 \text { days: } 33.3 \text { cf } 52.2 \\
\text { after } 12 \text { days: } 9.1 \text { cf } 40.5\end{array}$ & $p<0.01$ & \multirow[t]{2}{*}{$\begin{array}{l}\text { With honey, } \\
\text { epithelialisation was } \\
\text { more rapid and there } \\
\text { was less oedema } \\
\text { (both assessed } \\
\text { histologically). }\end{array}$} & \multirow[t]{2}{*}{97} \\
\hline & & & & $\begin{array}{l}\text { The thickness of granulation tissue } \\
\text { (mm, assessed histologically) with the } \\
\text { honey treatment } \text { cf the thickness with } \\
\text { saline was: } \\
\quad \text { after } 4 \text { days: } 0.52 \text { cf } 0.389 \\
\text { after } 8 \text { days: } 1.17 \text { cf } 0.53 \\
\text { after } 12 \text { days: } 1.917 \text { cf } 0.995\end{array}$ & $p<0.01$ & & \\
\hline $\begin{array}{l}\text { Wounds created } \\
\text { by excising skin } \\
(2 \times 2 \mathrm{~cm})\end{array}$ & Saline & Rats & 20 & $\begin{array}{l}\text { The mean contraction in size of the } \\
\text { wounds was } 80 \% \text { with honey, } 55 \% \\
\text { with saline. }\end{array}$ & $p=0.001$ & & 98 \\
\hline $\begin{array}{l}\text { Wounds created } \\
\text { by excising skin } \\
(2 \times 2 \mathrm{~cm})\end{array}$ & Saline & Rats & 20 & $\begin{array}{l}\text { After } 10 \text { days the mean area of the } \\
\text { wounds was } 1.15 \mathrm{~mm}^{2} \text { with honey, } \\
2.38 \mathrm{~mm}^{2} \text { with saline. }\end{array}$ & $p=0.002$ & $\begin{array}{l}\text { There was histological } \\
\text { evidence of greater } \\
\text { granulation with } \\
\text { honey. }\end{array}$ & 99 \\
\hline $\begin{array}{l}\text { Wounds created } \\
\text { by excising skin } \\
(2 \times 2 \mathrm{~cm})\end{array}$ & No treatment & Rats & 12 & $\begin{array}{l}\text { The quantity of collagen synthesised } \\
\text { was increased by honey cf the control. } \\
\text { The degree of cross-linking of the } \\
\text { collagen in the granulation tissue was } \\
\text { increased by honey increased by } \\
\text { honey cf the control }\end{array}$ & $p<0.05$ & & 100 \\
\hline
\end{tabular}




\begin{tabular}{|c|c|c|c|c|c|c|c|}
\hline \multirow[t]{2}{*}{$\begin{array}{l}\text { Wounds created } \\
\text { by excising skin } \\
(2 \times 2 \mathrm{~cm})\end{array}$} & \multirow[t]{2}{*}{ No treatment } & \multirow[t]{2}{*}{ Rats } & \multirow[t]{2}{*}{12} & $\begin{array}{l}\text { The content in granulation tissue of } \\
\text { various markers of connective tissue } \\
\text { metabolism increased by honey cf the } \\
\text { control: } \\
\quad \text { protein } \\
\text { collagen } \\
\text { hexosamine } \\
\text { uronic acid }\end{array}$ & $\begin{array}{l}p<0.01 \\
p<0.01 \\
p<0.01 \\
p<0.001\end{array}$ & & \multirow[t]{2}{*}{101} \\
\hline & & & & $\begin{array}{l}\text { The rate of healing was increased } \\
\text { by honey cf the control: } \\
\text { contraction of wound } \\
\text { epithelialisation }\end{array}$ & $\begin{array}{l}p<0.001 \\
p<0.05\end{array}$ & & \\
\hline $\begin{array}{l}\text { Incision }(6 \mathrm{~cm} \\
\text { long) made in } \\
\text { skin, then sutured }\end{array}$ & No treatment & Rats & 12 & $\begin{array}{l}\text { The tensile strength of the wounds } \\
\text { was increased by } 21 \% \text { with honey cf } \\
\text { the control. }\end{array}$ & $p<0.05$ & & 101 \\
\hline $\begin{array}{l}\text { Full-thickness } \\
\text { incisions }(3 \mathrm{~cm} \\
\text { long) made in the } \\
\text { skin }\end{array}$ & No treatment & Rabbits & 40 & $\begin{array}{l}\text { Honey increased the strength of the } \\
\text { healed wounds compared with the } \\
\text { untreated control: } \\
\text { tensile strength (measured after } 14 \\
\text { days) } \\
\text { ultimate strength } \\
\text { yield strength }\end{array}$ & $\begin{array}{l}p<0.001 \\
p<0.05 \\
p<0.02\end{array}$ & $\begin{array}{l}\text { Less oedema was } \\
\text { observed with the } \\
\text { honey treatment, and } \\
\text { histological } \\
\text { examination revealed } \\
\text { that honey gave less } \\
\text { inflammation and } \\
\text { necrosis and more } \\
\text { fibroblasts and } \\
\text { collagen present. }\end{array}$ & 102 \\
\hline
\end{tabular}




\begin{tabular}{|c|c|c|c|c|c|c|}
\hline $\begin{array}{l}\text { Full-thickness } \\
\text { incisions }(1.5 \mathrm{~cm} \\
\text { long) made in the } \\
\text { skin }\end{array}$ & No treatment & Rats & 6 & $\begin{array}{l}\text { Histological examination of biopsy } \\
\text { samples showed: } \\
\text { with honey, on Day } 7 \text { there was } \\
\text { epithelial bridging cf inflammatory } \\
\text { exudate and no epithelialisation } \\
\text { with the control; } \\
\text { with honey, on Day } 14 \text { there was } \\
\text { complete epithelial bridging with } \\
\text { honey cf epithelium yet to cover } \\
\text { wound with the control. }\end{array}$ & Not given & 103 \\
\hline
\end{tabular}


